\title{
REFLEXIA EURÓPSKYCH HODNÔT V SÚČASNOM SLOVENSKOM DIVADLE
}

\author{
ELENA KNOPOVÁ \\ Ústav divadelnej a filmovej vedy Centra vied o umení Slovenskej akadémie vied, Bratislava
}

\begin{abstract}
Abstrakt: Štúdia sa venuje identifikácii reprezentatívnej vzorky tém, ktoré vstúpili do umeleckého i spoločenského diskurzu prostredníctvom inscenačnej tvorby v slovenských repertoárových divadlách v ostatných troch rokoch (2016 - 2018). Nahliada na ne implicitne z perspektívy dramaturgie tém a tzv. postdramaturgie pocitov, ako aj z perspektívy európskych hodnôt, zaznamenaných $\mathrm{v}$ aktuálnych sociologických prieskumoch. Autorka sa porovnaním výsledkov Európskeho výskumu hodnôt (European Values Study), cielov a hodnôt reprezentovaných Európskou úniou ako spoločenstvom a tém, ktoré nastolilo slovenské divadlo (tzv. zriad’ované a repertoárové divadlá), pokúša zistit, či alebo ako korešponduje naše divadlo prostredníctvom reflexie tém a ich interpretácie s postojmi slovenských a európskych občanov, a to napríklad v otázkach identity, rodiny, ohrozenia, tolerancie, islamizácie starého kontinentu, ochrany demokracie, ale i legitimizácie liberalizácie tradičných hodnôt.
\end{abstract}

Kl'účové slová: hodnoty, súčasné slovenské divadlo, European Values Study, kríza, anticipácia

V západnej kultúre (teórii i praxi) divadlo z hl'adiska jeho funkcií už dávnejšie nevnímame iba ako umenie či umelecký dramatický druh. Jeho vývin minimálne od antických čias potvrdzuje, že niekedy sporadicky, inokedy nástojčivo reagovalo na spoločenské deje, ovplyvňovalo ich, ba dokonca do spoločenskej sféry aktívne zasahovalo. Je to jeho danost' vychádzajúca z mimetického princípu ako umeleckého napodobňovania skutočnosti, ale aj z úzkeho a bezprostredného prepojenia na svoju dobu, človeka, spoločnost’ a v nej prebiehajúce procesy. Divadlo na jednej strane vždy bojovalo o svojský a originálny divadelný, resp. scénický výraz a jazyk, na strane druhej či paralelne sa sebadefinovalo ako umenie posolstva, správy o stave človeka a sveta, reflektujúc dokonca vlastné vzd’al'ovanie sa od ucelenej jednoty, ktorú mu kedysi ponúkali mýty a rituály. Zväčša na lokálnom materiáli hl'adalo (nezriedka metaforicky a kriticky) širšie presahy, nadčasovú platnost', upozorňovalo aj na spoločenskú periodicitu v inscenáciách zachytených dejov, javov, mravov, pozitív i negatív, hoci v pozmenenej podobe. Samozrejme, divadlo by nemalo zabúdat' na svoj umelecký status a autentické tvorivé zdroje, ktoré sa od základnej divadelnej znakovosti neustále rozširujú, ani na svoju danost’ jedinečnej živej komunikácie. V tom tkvie jeho estetická, emocionálna a etická hodnota, akási základná divadelná trojnožka, vrátane napr. zábavnej, ludickej alebo edukatívnej funkcie. V súčasnosti sa však uplatňujú tendencie, ktoré roztvárajú hranice umenia či artistnosti smerom k spoločnosti, človeku ako súčasti spoločensko-politického systému. Divadelné postavy tak budia skôr zdanie vykoreneného, no nie vždy integrálneho zástupcu celku (spoločenstva) než zretel'nej singulárnej individuality (jednotlivec ako hrdina), ktorá na tejto báze buduje vztahy s ostatnými postavami a svojím okolím, alebo sa intímne ponára do svojho izolovaného vnútra a prináša akési všeobecne platné (nové) poznanie. 
Rovnako ako v Európe, aj na Slovensku zaznamenávame prívlastky a požiadavky na divadlo, ktoré by malo byt’ umeleckým médiom autentickým, (občiansky) angažovaným, participačným, sociálneho aktu, politickým atd’. Laureát Nobelovej ceny za literatúru, britský dramatik Harold Pinter sa dokonca v roku 2006 počas Európskej ceny za divadlo, ktorú mu udelili za celoživotné dielo, vyjadril, že je skoro nemožné, aby sa špičkové európske divadlo dnes nevyjadrovalo politicky. ${ }^{1}$ Používame označenie európske divadlo, európska dráma, no v skutočnosti divadlo do tejto skupiny zarad’ujeme na základe geografickej príslušnosti k „starému kontinentu“. Len zriedkavo sa stretávame s tým, že by divadelní tvorcovia na Slovensku aj v ostatných európskych krajinách zachytávali čosi, čo by sme mohli nazvat’ celistvou alebo všeobecne akceptovanou európskou entitou. Teatrológ Miloš Mistrík sa napríklad k vztahu slovenského divadla a európskej divadelnej kultúry vyjadril nasledovne: „Slovenské divadlo vnímame ako jednu zo samostatných zložiek európskej kultúry, jednu z európskych entít. Naše divadlo absorbovalo a absorbuje mnohé vplyvy zo zahraničia. Predovšetkým vd’aka uvádzaným cudzím dramatickým autorom, ktorých diela $\mathrm{v}$ procese inscenovania prechádzajú interpretačným, a tým aj akýmsi nostrifikačným procesom. Uvedenie cudzieho autora je vždy aj jeho zapojením do nášho ideového a sociálneho kontextu. ${ }^{2}$

Celkom prirodzene sa stretávame s regionálnejším tematickým zameraním. U nás, podobne ako v okolitých postsocialistických štátoch, výrazne vystupujú do popredia vyslovene lokálne, do vnútra krajiny orientované témy, ktoré divák bez znalosti domáceho kontextu niekedy nie je schopný rozpoznat’ a kriticky spracovat. Nie sú teda súčastou prirodzených európskych divadelných transferov, ani dostatočne všeobecne spoločensky známe. Dokonca aj pri inscenáciách inonárodnej drámy sa tvorcovia viac zameriavajú na nachádzanie jej podobností s pomermi "tu vnútri“. Len málo inscenácií sa venuje problémom a témam pochádzajúcim a smerujúcim "tam von“, alebo ich interpretujú z európskej perspektívy/perspektívy európskeho spoločenstva. Európsku kultúru zvykneme vnímat ako staré hodnotové usporiadanie a skúsenosti (známa koncepcia anticko-krestanskej skúsenosti). Dnešné európske spoločenstvo však stále nedokážeme hodnotovo presne charakterizovat', ani divadelne uchopit', napriek jeho geopolitickej „legitimizácii“ v podobe Európskej únie v roku 1993. Filozofi a estetici ohlasujú a argumentujú skôr rozklad spomenutej „starej skúsenosti“ (racionalizácia z celku vytrhnutých častí, relativizácia ako metóda vyhodnocovania, bezbrehá pluralita a naopak enigmatický subjektivizmus ako analytické perspektívy a pod.) $)^{3}$ než vytvorenie nového akceptovatelného hodnotového kódexu.

Môžeme vyslovitł otázku, či akási vnútorná európska entita alebo identita nie je z pohladu divadelného umenia len pomerne hmlistý koncept, zastrešený vonkajšími

${ }^{1}$ Viac o téme pozri KNOPOVÁ, E. Európska cena za divadlo 2006 alebo Je skoro nemožné, aby sa špičkové európske divadlo dnes nevyjadrovalo politicky. In Slovenské divadlo, 2006, roč. 54, č. 3, s. $451-454$.

${ }^{2}$ MISTRÍK, M. Slovak Theatre as a European Entity. In KNOPOVÁ, Elena (ed.). Theatre as a Value-based Discourse. Slovak Theatre and Contemporary European Theatre Culture. Bratislava : Veda, 2018, s. 13.

${ }^{3}$ Vzt’ah medzi konceptmi a hodnotovými systémami sa skomplikoval, hodnoty už netvoria podklad subjektivizmu ako istý holistický prvok, pretože prvkom života subjektu meniaceho sa na individualistu sa namiesto pravdy či pravdivosti stala ilúzia. Bližšie pozri napr. ZIMA, P. V. Theorie des Subjekts: Subjektivität und Identität zwischen Moderne und Postmoderne. Tübingen : UTB / Francke, 2000; BAHR, H. Zur Überwindung des Naturalismus. Weimar: VDG Verlag, 2004. 
štruktúrami a poriadkom. A či európske divadlo na ňu nenahliada vo svojej pluralite skôr ako na mozaiku poskladanú z pevne ohraničených častí, ktoré až následne tvoria celok - obraz, príbeh, spoločný pocit, prípadne skúsenost' atd'., teda jednotlivosti tvoria a vplývajú na celok samovolne. Pokúsme sa túto hypotézu preskúmat z pozície súčasného slovenského divadelného vývinu a súčasných divadelných pohybov.

V roku 2004 sa Slovensko stalo súčastou Európskej únie (EÚ). Podobne ako po rokoch 1989 či 1993 sa slovenská spoločnost’ opät’ ocitla v nových podmienkach, ktoré, ako dnes vidíme, majú značný vplyv tak na formovanie európskeho diania, ako aj následného diania na úrovni jednotlivých štátov a národov EÚ, smerovanie teda ide od celku k jednotlivostiam. Tieto procesy nás síce prvotne formovali zvonku, ale následne sme si museli na základe dohody či aliancie osvojit’ stanovené, resp. konštruované znenia istých zásad a ciel'ov, ktoré má moderná Európa dosahovat’ a chránit’. S ktorými z nich sa však slovenské divadlo identifikovalo, prevzalo ich ako hodnoty, ktoré artikuluje, háji, či naopak kritizuje? Teda, ktoré sformulovalo ako dôležité takpovediac zdola a obsiahlo ich vo svojich inscenáciách, v nich nastolených témach a tematických interpretáciách? Pri hl'adaní odpovedí na tieto otázky sa zameriame na tzv. koncept dramaturgie tém ${ }^{4}$, konkrétne na témy, ktoré prostredníctvom dramaturgií jednotlivých divadiel začali na naše javiská a azda aj do spoločnosti vstupovat’ po roku 2015 ako tie, ktoré mali byt’ spoločensky zásadné. Časový horizont je zvolený zámerne. Predchádzajúce obdobie od roku 1989 je pomerne vyčerpávajúco spracované v kolektívnej monografii Súčasné slovenské divadlo v dobe spoločenských premien. Pohl'ady na slovenské divadlo 1989 - 20155 , a preto sa pokúsime pozriet' na niekol'ko nasledujúcich dramaturgických smerovaní v ostatných troch rokoch (2016 - 2018).

Toto obdobie je zaujímavé nielen z hl'adiska kontinuálneho prístupu k poznávaniu súčasného slovenského divadla, ale aj z d’alšieho dôvodu. Od roku 1983 (na Slovensku od roku 1991) sa uskutočňuje Výskum európskych hodnôt (European Values Study, skratka EVS), ktorý je najstarším komparatívnym výskumom hodnotových orientácií v Európe. Prebieha v devätročných cykloch, pričom zatial' posledné dostupné výsledky tohto výskumu máme $\mathrm{k}$ dispozícii z roku 2017.6 Cielom výskumu je sledovat kontinuitu a zmeny $\mathrm{v}$ hodnotách viažucich sa $\mathrm{k}$ najdôležitejším oblastiam l’udského života. Preto je zaujímavé pokúsit’ sa porovnat', aké hodnoty označovali Slováci a Európania za dôležité (alebo naopak), a ktoré identifikovalo ako nosné či potrebné umelecky spracovat’ a šírit’ naše divadlo. Základné oblasti výskumu a výsledky EVS predstavíme v štúdii neskôr. Zatial' spomeňme len to, že takmer vo všetkých stanovených oblastiach sa Slovensko priblížilo k európskemu priemeru. Môžeme tvrdit, že v niektorých oblastiach viažucich sa na individuálne hodnotové postoje, teda napr. v otázkach osobných hodnôt, sa naši občania prejavili ako liberál-

${ }^{4}$ Bližšie pozri VEDRAL, J. Horizont události. Praha - Bratislava : Nakladatelství Pražská scéna - Ústav divadelnej a filmovej vedy SAV, 2015, s. $264-266$.

${ }^{5}$ KNOPOVÁ, Elena (ed.). Súčasné slovenské divadlo v dobe spoločenských premien : pohl'ady na slovenské divadlo 1989-2015. Bratislava : Veda : Ústav divadelnej a filmovej vedy SAV, 2017.

${ }^{6}$ Spoločným garantom projektu EVS je medzinárodná metodologická skupina pri University of Tilburg v Holandsku. Zber údajov pre výskumnú vlnu EVS 2017 prebiehal v krajinách Európy od septembra 2017.

Sociologický ústav SAV bol garantom slovenskej časti EVS od roku 1999. Bližšie pozri Naše európske hodnoty 2017. Komentár k zisteniam slovenskej časti výskumu európskych hodnôt EVS 2017. [Tlačová správa]. [cit. 10. 10. 2019]. Dostupné na internete: http://www.sociologia.sav.sk/cms/uploaded/2786_attach_EVS_ SK_2017_tlacova_sprava\%20final.pdf. 
nejší a zmierlivejší, kým v otázkach verejnej sféry a riešenia verejných problémov ako prísnejší a kritickejší než občania v iných európskych krajinách.

Na tému reflexie hodnôt $\mathrm{v}$ divadle nie je možné nazerat časovo úplne selektívne. Pripomeňme si niekol'ko najvýraznejších tendencií ešte spred roka 2015. V spomenutej monografii o súčasnom slovenskom divadle nachádzame východiskový rámec, ktorý už vtedy nepozeral na slovenské činoherné, repertoárové - čiže zriad’ované - divadlo izolovane. Vnímal ho ako divadlo, ktoré by malo plnit aj reflexiu európskeho priestoru a utvárat’ medzikultúrny a hodnotový dialóg, nie iba ponúkat viac či menej divácky úspešné inscenácie, tematicky sa uzatvárajúce dovnútra našej krajiny: „Paralelne s existenciálnymi zmenami, ktoré u nás prebiehali, otvoril sa priestor na nadviazanie úzkeho dialógu divadelnej dramaturgie (divadelnej tvorby) s divákmi prostredníctvom spoločensko-umeleckej participácie na týchto procesoch a ich spoločensko-umeleckej reflexii. Stali sme sa súčastou dejov, ktoré mali priam celosvetový vplyv a výrazný dosah na život jednotlivcov (ekonomickú, sociálnu, pracovnú, rodinnú oblast’ a pod.), na ich životný štýl i spôsob myslenia. Naše divadlo sa nachádzalo vo výnimočnom bode, z ktorého mohlo vstúpit do európskeho priestoru ako divadlo výsostne skúsenostné a aktuálne. Núkala sa možnost’ aktívneho umeleckého dialógu s postsocialistickou i západnou divadelnou kultúrou. Nestalo sa tak. ${ }^{\prime 7}$

Citát naznačuje oslabené presahy v oblasti nových impulzov, ktoré by divadlo malo vnášat do spoločenského a umeleckého diskurzu. S tým korešpondovali aj témy, ktoré môžeme z vývinového hl'adiska považovat' za reagovanie divadla na požiadavku väčšej angažovanosti, prichádzajúcu aj z radov kritickej obce. Pohl'ad do nedávnej minulosti ukázal, že v období 1990 - 2015 sa pomerne zásadnou témou ukázalo byt๋ vyrovnávanie s násilím rôzneho druhu - od násilia páchaného v mene náboženského presvedčenia cez násilie páchané z dôvodu netolerantnosti voči inému názoru a vierovyznaniu až po traumy zo stále citlivo vnímanej minulosti, ktorou bola 2. svetová vojna, neprevzatie zodpovednosti za holokaust, za našu komunistickú minulost' a pod.

V inscenáciách devätdesiatych a nultých rokov bol divákom sprostredkovávaný svet plný zdevastovaných hodnôt. Predovšetkým išlo o narušenie tradične chápaných a spoločensky i politicky ustanovených krestanských hodnôt na osi morálne - amorálne, ale aj spochybnenie rodových a rodinných identít či problematizovanie lásky a viery ako duševných a duchovných nastavení. Akoby v živote dnešného človeka neexistovala nádej na štastie, mravnosť či pozitívne city. Svet, ktorý sa ukazoval na javiskách, spel do záhuby, ale nahliadalo sa naň ako na všeobecnú entitu. Civilizácia sa ocitla na konci epochy, ktorá zavrhla všetky doterajšie hodnoty, ale nové ešte nestihla stvorit’ alebo ustanovit. Obzvlášt také, ktoré by ponúkali l'udstvu pozitívnu víziu do budúcna.

Neskôr, najmä po roku 2005 (medzníkom bola inscenácia Tiso Divadla Aréna v réžii Rastislava Balleka uvedená v tomto roku) prichádzali inscenácie nasmerované do vnútra našej krajiny i dejín, ktoré otvárali najmä tému viny a prevzatia zodpovednosti. Korešpondovali s tendenciou prítomnou vo viacerých divadlách - inscenovat hry venované politickým osobnostiam slovenských štátnych dejín. Tvorcovia prostred-

${ }^{7}$ KNOPOVÁ, E. Činoherná dramaturgia v nových podmienkach a súvislostiach. In KNOPOVÁ, Elena (ed.). Súčasné slovenské divadlo v dobe spoločenských premien : pohl’ady na slovenské divadlo 1989-2015, s. $71-72$. 
níctvom nich priniesli do divadelného kontextu iný uhol pohladu, poukazujúci na problém súčasnej relativizácie. Relativizácia, na ktorú divadelníci upozorňovali, súvisela s mierou zrelosti a schopnosti slovenských súčasníkov vyhodnocovat’ dnešné postoje $\mathrm{v}$ širších historických súvislostiach. Tematizovala sa najmä dispozícia odpútat' sa od starých mechanizmov zla v záujme toho, aby sa história nezačala opakovat'.

Morálka a vyznávané hodnoty dnešnej spoločnosti a človeka sa ako téma objavovali v inscenáciách skôr implicitne, ako súčast’ motivácií a činov postáv. Po roku 2010 však vystúpila do popredia ojedinele aj ako ústredný subjekt - mnohorako preverovaná a overovaná nepriama postava. To znamená, že tvorcovia konkrétne tematizovali súčasný hodnotový kódex a hl'adali, či jestvuje morálka nového človeka. ${ }^{8}$ Spoločnou črtou inscenácií bolo artikulovanie vzniku pamätových dier, nivelizácie problémov, no najmä relativizovanie hodnôt. Vyvstávajúcimi hodnotami sa ukázali byt' pamät', história, osobná a národná identita, zodpovednost’ za svoju minulost' (aj tú menej svetlú), kultúrne korene a budúcnost'. Môžeme si položit’ otázku, či slovenské divadlo v rokoch 1989 - 2015 anticipovalo alebo neanticipovalo deje, prípadne „Zeitgeist“, vedúce k formulovaniu postojov k problémom dneška, ktoré sa vynorili a pohltili takmer celú Európu aj okolitý svet. Máme tým na mysli napr. nárast extrémistických a nacionalistických nálad, občiansku nespokojnost', politickú nestabilitu, akúsi návalovú disharmóniu medzi osobným a verejným (sektorom) vedúcu až k demonštráciám, pochodom, ozbrojeným útokom, verejnému vandalizmu, nepokojom, dokonca občianskym vojnám. To všetko v bezprostrednej blízkosti Slovenska alebo priamo vo vnútri krajiny.

Slovenské divadlo v ostatných dvoch až troch sezónach (teda v rokoch 2016 2018) $)^{9}$ bolo kritikmi pozitívne označované ako divadlo, ktoré prevzalo zodpovednost', je aktuálne a angažuje sa. Tieto označenia môžeme však podrobit tiež kritickejšej konfrontácii z pozície samotného statusu divadelného umenia a vyslovit protichodnú otázku, či sme sa nestretali s inscenáciami, ktoré zachytávali aktuálne akcentované spoločenské problémy (napr. extrémizmus spojený s vedúcou osobnostou politickej parlamentnej strany L'udová strana Naše Slovensko Mariánom Kotlebom, neofašizmus oživený práve pôsobením tejto strany a jej ideových stúpencov, špinavé praktiky spojené s kauzou objednanej vraždy novinára a jeho snúbenice atd’.), alebo sa (obzvlášt vd’aka stému výročiu Československej republiky) navracali k osobnostiam a témam demokracie a nedemokracie, avšak bez ambície „onej“ jednoty poznania, presahu od jednotlivých prepojení k celistvosti javu.

Divadlo sa miestami začalo správat ako informačné či mienkotvorné médium (podobne ako televízia alebo printové, prípadne internetové noviny), ale neanalyzovalo problémy umeleckým spôsobom. Nehl'adalo ani nesmerovalo k podstate poznania, pravdivosti sprostredkovanej práve divadlom, len načrtávalo a konštatovalo, zapájalo sa do neformálneho vzdelávania a momentálnych spoločenských káuz. Umelecký nadhl'ad vystriedala promptnost’ v reagovaní na dianie tu a teraz, čo bolo typické skôr pre malé, nezávislé divadlá než tzv. divadelné domy. Toto opakované sústredenie sa na momentálny stav však zároveň môže byt’ pre divadlo rizikom. Artikulácia najviditel'nejších a v danom momente rezonujúcich problémov (príp. na druhej strane spoliehanie sa na tzv. inscenačné istoty - niečím vábivé a provokatívne témy) môže

\footnotetext{
${ }^{8}$ Porov. tamže, s. $70-154$.

${ }^{9}$ Ide stále o tvorbu tzv. kamenných divadiel.
} 
divadlo izolovat'. Vývinovo sa môže zopakovat' história, ked' strata nepriatel'a napr. $\mathrm{v}$ podobe komunistickej moci viedla $\mathrm{v}$ slovenskom divadle $\mathrm{k}$ strate témy a celkovej stagnácii divadelnej tvorby. Istou záchranou takéhoto dramaturgického postupu sa javilo byt' samotné európske spoločensko-politické dianie, a síce naprieč Európou sa šíriace podobné deje a nálady (napr. migrantská kríza, nacionalistické pnutia, militantné nepokoje a terorizmus).

Vrátme sa na tomto mieste k úvodnej hypotéze, týkajúcej sa európskej entity ako zvnútra vybudovaného a sceleného (čiže do istej miery homogenizovaného) spoločenstva. Pokúsme sa hl'adat’ odpovede na to, či nám divadlo neanticipuje aj čosi zásadné, čo stojí nad divadelnou metaforou alebo kritikou obsiahnutou v jednotlivých inscenáciách, nad nimi nastolenou tematickou agendou ostatných dvoch rokov. Pomôžeme si pri tom verejne známymi a všeobecne uznanými ciel'mi EÚ, výsledkami výskumu EVS a trendmi vo vývoji hodnôt, ktoré tento výskum priniesol. Medzi základné ciele EÚ patrí presadzovanie mieru, hodnôt a blaha občanov, zaistenie slobody, bezpečnosti a spravodlivosti bez vnútorných hraníc, trvalo udržatel'ný rozvoj, boj proti sociálnemu vylúčeniu a diskriminácii na základe pohlavia, rasy alebo etnického pôvodu, náboženstva alebo viery, zdravotného postihnutia, veku alebo sexuálnej orientácie, podpora zamestnanosti a vzdelávania, podporovanie sociálnej spravodlivosti, rovnosti medzi ženami a mužmi, solidarity medzi generáciami, podpora vedeckého a technologického pokroku, ochrana životného prostredia, zlepšenie hospodárskej, sociálnej a územnej súdržnosti a solidarity medzi členskými krajinami, ochrana bohatej kultúrnej a jazykovej rozmanitosti. ${ }^{10}$ Tieto ciele sa ako témy, ba dokonca divadelné programy dostali do pozornosti divadelníkov najmä v oblasti nezávislého, komunitne orientovaného divadla. Spomeňme napríklad tvorbu Divadla Pôtoň (nútené presídl'ovanie obyvatel'stva, chudoba, téma násilia a extrémistických inklinácií na úrovni individuálnej, spoločenskej i politickej), Divadla z Pasáže (divadlo pracujúce s marginalizovanými skupinami), Divadla No Mantinels (LGBTI komunita) či Bábkového divadla na Rázcestí (feministické témy a témy rodovej citlivosti).

Hodnoty EÚ by mali byt’ spoločné pre všetky členské krajiny a ich občanov čiže celú spoločnost'/európske spoločenstvo, v ktorom by mali vládnut' začlenenie, tolerancia, spravodlivost', solidarita a nediskriminácia. Všeobecne uznanými európskymi hodnotami, ktoré majú podliehat’ rozširovaniu a zároveň ochrane, sú napr. úcta k l'udskej dôstojnosti, sloboda, demokracia, rovnost', právny štát, rešpektovanie l'udských práv, vrátane práv osôb patriacich k menšinám. ${ }^{11}$ Ludská dôstojnost' pritom predstavuje skutočné východisko základných práv, preto sa musí rešpektovat a chránit'. Sloboda sa spája najmä so slobodou pohybu. Pre divadlo sú smerodajné skôr hodnoty osobnej slobody, ako je napr. rešpektovanie súkromného života, sloboda myslenia, náboženského vyznania, zhromažd’ovania, prejavu, slobodný prístup k informáciám (čiže odmietnutie cenzúry a ideologického diktátu). Demokracia znamená mat’ politické práva a rešpektovat' ich. Rovnost’ znamená rovnaké práva pre všetkých občanov pred zákonom, zásada rovnosti platí aj genderovo (čiže medzi ženami a mužmi), nielen z hl’adiska sociálnej stratifikácie, komunitnej, rasovej,

\footnotetext{
${ }^{10}$ Ciele a aktivity Európskej únie (Zmluva o EÚ) [online]. [cit. 13. 6. 2018]. Dostupné na internete: https:// www.lewik.org/term/7496/ciele-a-aktivity-europskej-unie-zmluva-o-eu/.

${ }^{11}$ Ludské práva v EÚ [online]. [cit. 23. 8. 2018]. Dostupné na internete: http://eu.euroiuris.sk/pre_ pedagogov/ludske_prava_v_eu.
} 
národnej či národnostnej príslušnosti a pod. Právny štát by mal zase chránit právo a spravodlivost', zabezpečovat’ a strážit' legálnost' a transparentnost' procesov, a to tak vo sfére organizovania a spravovania vecí verejných (vrátane nakladania s verejnými finančnými zdrojmi), ako aj vo sfére týkajúcej sa súkromného a podnikatel’ského sektora. Rovnako by mal však dbat’ na práva jednotlivcov, ich ochranu, a to všetko predovšetkým prostredníctvom dôkladne (svedomito) nastavenej legislatívy a skrze fungujúce nezávislé súdnictvo. L’udské práva predstavuje najmä nediskriminácia na základe pohlavia, rasy alebo etnického pôvodu, náboženstva alebo viery, zdravotného postihnutia, veku alebo sexuálnej orientácie, právo na ochranu osobných údajov a právo na prístup $\mathrm{k}$ spravodlivosti.

Tieto hodnoty by teda mali byt’ neoddelitel'nou súčastou nášho európskeho spôsobu života a teoreticky by sa mali objavit’ ako súčast’ divadelných inscenácií, divadelného diskurzu. ${ }^{12}$ Celý tento komplex vyššie spomenutých cielov a hodnôt vlastne predstavuje nastavenia príznačné pre súčasný európsky kontext a jeho hodnotový horizont. Zároveň naznačuje, že by v takto nastavených schémach, na osi ich narúšania či potvrdzovania, mali byt’ potenciálne vnímané a reflektované aj prostredníctvom divadelnej tvorby. A to celkom prirodzene, pretože na jednej strane pochádzajú z dlhoročnej spoločenskej a kultúrnej skúsenosti, ktorá stále čerpá prevažne z antického a krestanského hodnotového a morálneho „kódexu“, a na strane druhej aj z vízií stabilnej a lepšej budúcnosti. Vnímanie jednotlivca teda nevytrhávajú z jeho prirodzeného prostredia a vývinového procesu, naopak, poskytujú mu jasný referenčný rámec.

Pozrime sa teraz na niektoré konkrétne vyznávané hodnoty a postoje občanov Slovenskej republiky, ktoré sa prostredníctvom EVS preukázali, resp. ich môžeme sledovat’ v istej vývinovo-trendovej kontinuite v európskom rámci. ${ }^{13}$ Medzi dôležité hodnoty patria napr. udržanie vysokej dôležitosti rodiny a práce v živote obyvatelov, pokračujúci rast vel'kého významu priatel’ov, známych a vol’ného času. Obsahová premena nastala $\mathrm{v}$ chápaní vztahu medzi manželstvom a zakladaním rodiny: manželstvo je vnímané ako zastaraná inštitúcia, dokonca nie potrebná k vytváraniu pocitu štastia. Avšak čo sa týka rodiny, pretrváva rodovo vyvážený model verných heterosexuálnych rodičov, ktorí dokážu vytvorit’ atmosféru porozumenia a uznania, obetujú sa pre svoje deti a deti sú povinné preukazovat’ v každom ohl'ade úctu k rodičom. Rovnaké vierovyznanie a sexuálna spokojnost’ už nie sú vnímané ako dôležité, rovnako tak vytvorenie samostatného modelu či domácnosti (t. j. žit oddelene od príbuzných). Pokračuje trend nárastu spoločenského súhlasu s rozhodnutím ženy mat dieta, vychovávat' ho sama a žit bez muža, čo vypovedá práve o dôležitosti aktu založenia rodiny a dôležitosti detí pre naplnenie žien pri neklesajúcej podpore významu práce v živote žien.

${ }^{12}$ Projekt, resp. niekolkoročná platforma Európa hodnôt (http://cep.sk/europa-hodnot/) prišiel s predpokladom a zároveň rozširovaním vedomia o tom, že ked' sa EÚ podarí dostat' cez plnenie prevažne ekonomických kritérií, prídu na rad aj otázky hodnôt. Cez tento projekt vstupovali do verejných diskusií témy: aké sú hodnoty v každodennom i politickom živote, v ekonomike, moc a peniaze, interkultúrny dialóg, etika v časoch krízy, bioetika ako i krest’anstvo a komunizmus. Napokon sa aktéri projektu v roku 2016 opät vrátili k základnej téme: čo sú európske hodnoty, akým výzvam dnes čelia a ako ich komunikovat', najmä mladým l’ud’om.

${ }^{13}$ Nasledovný vyznačený text vychádza z dokumentu Naše európske hodnoty 2017. Komentár k zisteniam slovenskej časti výskumu európskych hodnôt EVS 2017. [Tlačová správa]. [cit. 10. 10. 2019]. Dostupné na internete: http://www.sociologia.sav.sk/cms/uploaded/2786_attach_EVS_SK_2017_tlacova_sprava\%20final.pdf; a z porovnania s dokumentmi EVS 1999 - 2000 zverejnenými na http://www.sociologia.sav.sk/old/evs.html. 
Zmeny nastali v názoroch na výchovu detí, kde boli významne častejšie uvádzané vlastnosti ako samostatnost', pracovitost', vytrvalost', zodpovednost', šporovlivost' než slušné spôsoby, ktoré patrili k najčastejšie uvádzaným v minulosti. Pokračoval aj pokles dôležitosti vlastností ako znášanlivost' a ohl'aduplnost' $\mathrm{k}$ iným l'ud’om, viera či poslušnost'. Nárast zaznamenala všeobecná dôvera k iným l'ud’om (podiel sa takmer zdvojnásobil, avšak celkovo ostáva v populácii nad’alej nízky). Paradoxne, súbežne narástol odstup voči „iným“, odmietanie susedského kontaktu napr. s moslimami, zahraničnými robotníkmi, Rómami, ale aj Židmi. Nad týmito rasovými či etnickými predsudkami však prevláda udržanie pocitu bezpečia, a tak v ovel’a vyššej miere by si Slováci za susedov neželali l'udí so záznamom v trestnom registri, t’ažkých alkoholikov, drogovo závislých. Naopak, politickí (pravicovo či l'avicovo orientovaní) extrémisti, citovo nevyrovnané osoby, homosexuáli, HIV pozitívni nie sú ako potenciálni susedia vnímaní až tak negatívne. ${ }^{14}$

Výskum preukázal stagnovanie a pokles dôvery k väčšine spoločenských inštitúcií, vrátane cirkví. Namiesto tradičných krest’anských konceptov, ktorých dôveryhodnost' sa oslabuje, narastá viera v nekrestanský koncept reinkarnácie či viera v peklo (nie však v Boha). S tým azda súvisí aj pokles počtu praktizujúcich veriacich a pokles odsudzovania takých morálne sporných konaní, ktoré sú spájané s tradičnou krestanskou morálkou, napr. rozvod, nevera, samovražda, eutanázia, interrupcia, homosexualita. Prekvapivo zaznamenávame stabilitu v oblasti utilitárnej morálky a nárast odsúdenia takého správania, akým je branie úplatkov, politické násilie či zneužívanie štátneho aparátu. ${ }^{15}$ Výsledky prieskumu EVS (2017) sú zaujímavé, nakol'ko niektoré divadelné iniciatívy a inscenácie (či dokonca tendencie) s nimi hodnotovo korešpondujú. Je ich však menšina. Iné, početné divadelné počiny zase ukazujú ostrý nesúlad medzi tým, čo divadelní tvorcovia považujú za nosné témy a prínosné interpretácie, a tým, aký je názor či pocit občanov SR, ktorý sa približuje priemeru EÚ takmer vo všetkých kategóriách.

V rokoch 2016 - 2018 boli v slovenských divadlách stále živé témy národnej identity. Oproti predchádzajúcim obdobiam sa identita riešila v širších európskych súradniciach. Dopomohli k tomu príbehy tzv. rodinných ság či spoločenstiev. Nemenné je, že sa na identitu nahliadalo z perspektívy minulosti, prostredníctvom príbehov začínajúcich kdesi v 19. storočí, prípadne presahujúcich do 20. storočia, ale naše 21. storočie priamo z kultúrnej či politickej perspektívy divadelne nereflektovali. Aktualizáciu ako „t’ah na súčasnoste“ divadelníci ponechávali na divákov, azda trochu pohodlne sa spoliehajúc na presahy minulých dejov a ich okrajových podobností s dneškom, ktoré mali odhalit sami diváci. Pri politických témach divadelníci preferovali postupy oživovania a sprítomňovania dejov a problémov minulosti, len čiastočne ich aktualizovali (vyhýbali sa prísnemu historizovaniu) a vysúvali do popredia memento, aby sme nezabúdali na našu históriu, jej negatívne skúsenosti - na históriu ako strašiaka budúcnosti. V tomto smere boli o niečo pružnejšími nezávislé divadlá, čo samozrejme súvisí aj s ich spôsobom fungovania a práce, ktorý umožňuje rýchlejšie reagovat' na aktuálne procesy aj pri zostavovaní repertoáru.

Národnej povahe a sklonom rýdzo slovenským, ktoré podl'a tvorcov nezmenili podobu v našej spoločnosti, sa venovali inscenácie slovenských realistických drám

\footnotetext{
${ }^{14}$ Naše európske hodnoty 2017. Komentár k zisteniam slovenskej časti výskumu európskych hodnôt EVS 2017.

${ }^{15}$ Tamže.
} 


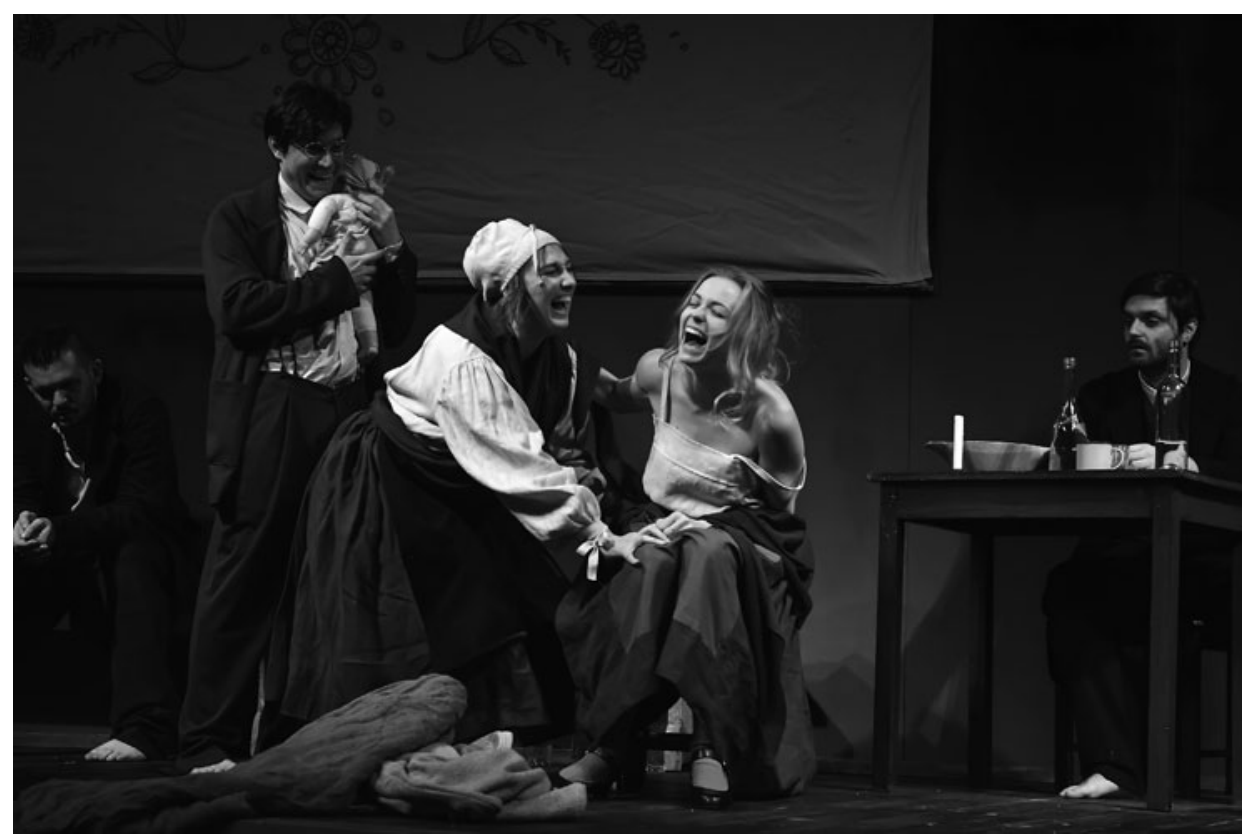

Božena Slančíková-Timrava: Ťapákovci. Divadlo J. Palárika v Trnave, premiéra 18. 2. 2017. Réžia Matúš Bachynec. Miroslav Beňuš (Martin Ťapák), Martin Križan (Čakaj Ťapák), Ingrida Baginová (Zuza), Petra Blesáková (Mara) a Tomáš Vravník (Pal’o Ťapák). Foto archív DJP. Snímka René Miko.

Ťapákovci (Divadlo J. Palárika v Trnave, 2017, réžia Matúš Bachynec) a Beta, kde si? (Divadlo J. G. Tajovského vo Zvolene, 2017, réžia Matúš Ol'ha). Beta, kde si? nahliadala cez dedinské postavy na Slovákov tradične, ako na spoločenstvo uzavreté, neschopné pružnej harmonizácie vzt’ahov, ale naopak čerpajúce z pretvárky, pokrytectva, bezohl'adnosti, neschopnosti prijat' individualitu vzd’alujúcu sa alebo prekonávajúcu skostnatené väčšinové konvencie (ako isté pseudohodnoty), teda neschopné prijat inakost’ ako pozitívny potenciál. Naproti tomu, Ťapákovci sa interpretačne posunuli od lenivosti a nedvižnosti k vedomému odmietnutiu pohybu. Konzervativizmus a uzavretost', nechcenie (nie neschopnost') komunikovat' a otvorit' sa okolitému svetu sú v tejto inscenácii povýšené na nemenné postoje, a preto sa človek voči nim nebúri. Ťapákovčina sa rodí už v jadre rodiny, domácnosti, jednotlivca ako vedomá letargia, preto aj spoločnosti chýba energia či vôla na realizovanie akýchkolvek premien. Podla kritičky Juliany Beňovej, inscenácia „vystavuje do popredia niektoré nemenné črty národnej povahy, ktoré ani po desatročia nevymizli - ostré riešenie malicherných sporov, opatrnost’ v prijímaní nového a progresívneho, tvrdohlavost', pasivita, nezmyselné zapáranie do druhých a nedostatok ambícií“16.

Kdesi medzi týmito dvoma inscenáciami sa nachádza inscenácia Jánošík (Divadlo A. Bagara v Nitre, 2017, réžia Rastislav Ballek) autorky Márie Rázusovej-Martáko-

${ }^{16}$ BEŇOVÁ, J. Uzavretost' a pasivita nezmizli z národnej povahy ani po storočí. In kød, 2017, roč. 11, č. 6 , s. $30-35$. 


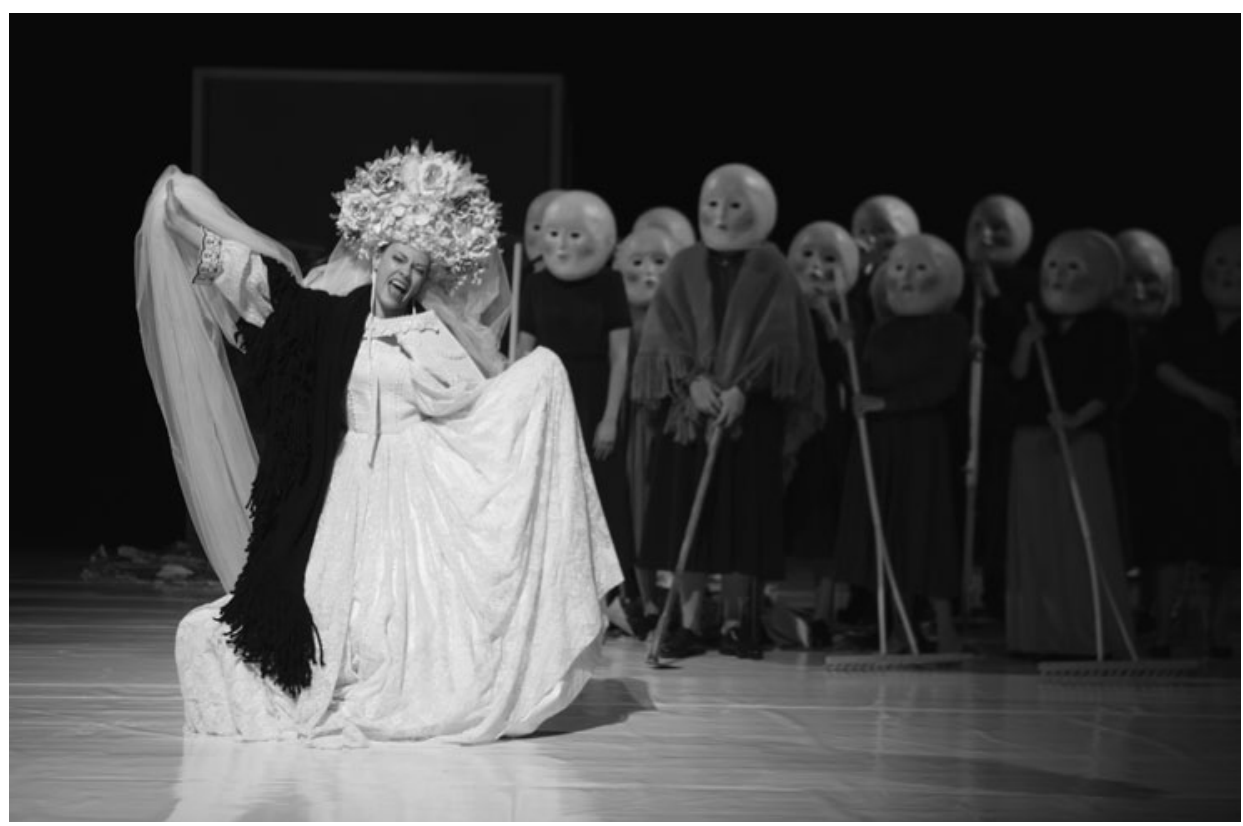

Mária Rázusová-Martáková: Jánošík. Divadlo A. Bagara v Nitre, premiéra 28. 4. 2017. Réžia Rastislav Ballek. Barbora Andrešičová (Víla). Foto archív DAB. Snímka Henrich Mišovič - Collavino.

vej, pôvodne proti vojnovému Slovenskému štátu nasmerovaná, neskôr zakázaná hra). Jánošík ako legenda je režisérom Rastislavom Ballekom dokonale deštruovaná. Režisér sa na hrdinu pozerá ako na radikálnu nonkonformitu, ktorá sa len časom vytvarovala do legendy odkazujúcej na akúsi nádej či záchranu slovenského l’udu. ${ }^{17}$ V inscenácii sa mihnú témy ako sloboda, právo, spravodlivost', kritika cirkvi, ktorá nevie bránit’ svojich poddaných, avšak celkovo ide o trpký úškrn nad stále vyhrávajúcim nespravodlivým systémom a legendou záchrany, ktorá je už od počiatku vyprázdnená, ba mŕtva. Jánošík sa síce posunul do society vzdelaných, a preto o tradičných nastaveniach spoločnosti a náboženských hodnotách pochybujúcich postáv, no v konečnom dôsledku sa mení na nehrdinu, na klamlivý mýtus, ktorý je nedvižný, nekonajúci, váhajúci a ani posvätenie víl mu nedá onú povestnú čarovnú silu, aby zvítazil. Na mýtus vracajúci sa naspät do prostredia slovenského l'udu, ktorý je vyobrazený ako tupý národ poddaných s gypsovými hlavami, ponevierajúcich sa v neporiadku v maličkom priestore. Zmenu optiky prináša postava Uhorčíka, ktorý sa radikalizuje. Ako extrémista s kanistrou a zapal'ovačom v rukách mieni vyčistit’ spoločnost’ od zla. Dost’ bolo filozofovania, teraz je potrebné, aby nastúpili činy, aj za cenu násilia: „... pripomína novodobého buriča, stúpenca radikalizmu Za Boha, za národ, neváhajúceho použit’ aj kanistru s benzínom na očistenie spoločnosti. Jeho myšlienky však majú aj logiku miestami s hrôzostrašným účinkom, sú reakciou na nerozhodnost', ,filozofovanie' v čase, ked’ treba konat'. "'18 Obe roviny sa stretajú

\footnotetext{
${ }^{17}$ BALLEK, R. Kritická platforma Dotyky a spojenia, príloha časopisu kød, 2018, roč. 12, č. 7, s. 22.

${ }^{18}$ PODMAKOVÁ, D. Alegorický obraz súčasného Slovenska. In Monitoring divadiel na Slovensku. [online].
} 


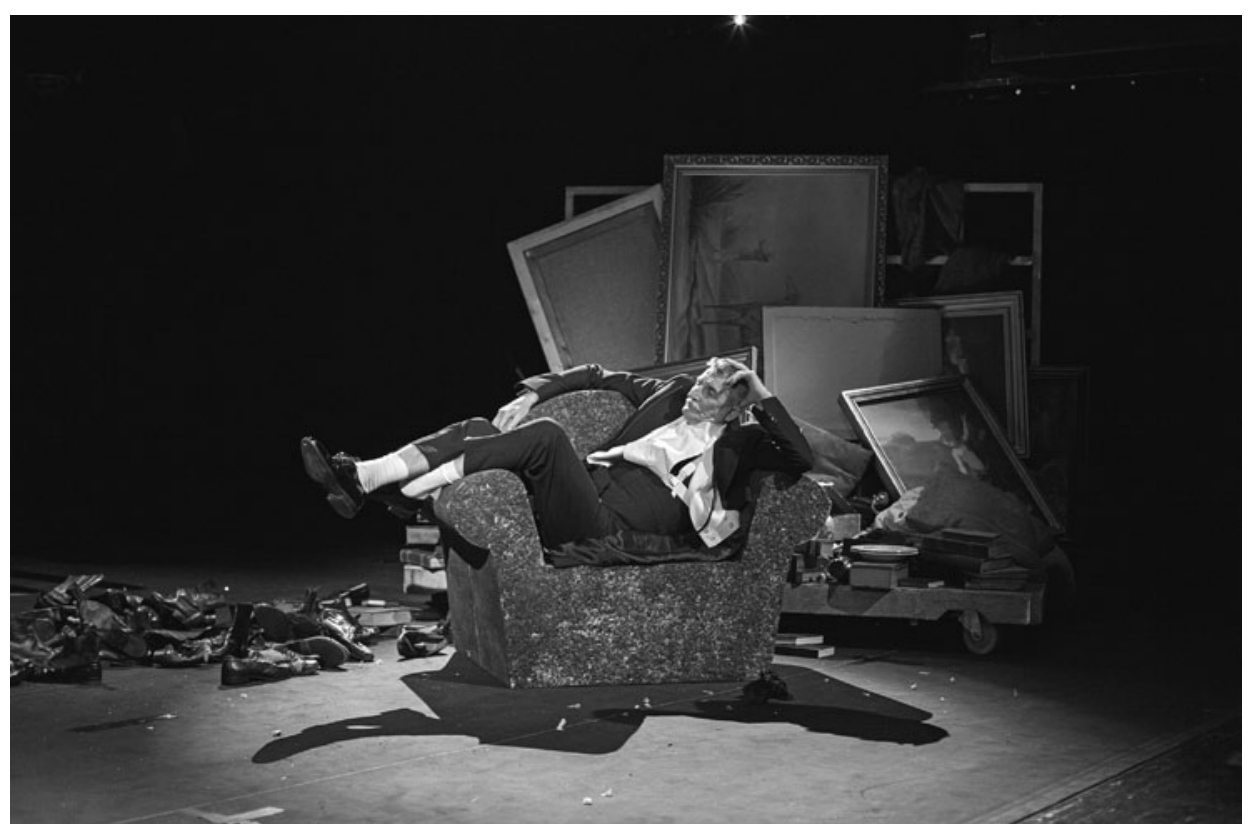

Péter Esterházy: Mercedes Benz. Slovenské národné divadlo, premiéra 7. 1. 2017. Réžia Roman Polák. Martin Huba (Pán). Foto archív SND. Snímka Andrej Čanecký.

v akomsi apokalyptickom vyznení či pohl’ade na riešenie našej spoločenskej situácie a na našu budúcnost́.

Inscenácie o slovenskej identite, ceste k slobode a právu implicitne prinášali témy vzbury, extrémnych rozhodnutí, rozhodnutí dat' dobe jej obete, aj na l'udských životoch, namiesto v našej predchádzajúcej divadelnej tvorbe zakoreneného martýrstva.

Tému dejín, ktoré nevyhnutne vyžadujú l’udské obete, priniesli inscenácie l’udských rodov, spoločenstiev a ság. V Mercedes Benz Pétera Esterházyho (Slovenské národné divadlo, 2017, réžia Roman Polák) sa zápas dobra a zla v človeku predostrel ako zábavka, hra medzi Bohom a Luciferom. Človek tento zápas o pozitívne hodnoty viac-menej prehrával, no s hlbokým porozumením pre dejinný vývin. Akoby dejiny formovali správanie človeka a nie naopak. Divadelná kritika zdôrazňovala aj v inscenácii marginálne rozohrané témy ako prejav angažovaného divadelného gesta (napr. holokaust; kto nemá dejiny, nemá minulost'; nacionalistické zneužitie hesla „Za Boha, za vlast', za národ či za rodinu“; za dejiny treba prevziat’ zodpovednost', ale „tu sa len rabuje $\mathrm{e}$ ). ${ }^{19}$ Záver inscenácie priniesol trochu kontroverzného „nacionálneho“ napätia: Mužské postavy reprezentujúce jednotlivé národy boli postavené pod šibenicu alebo dohnané k aktu samovraždy. Slováci na rozdiel od iných stredoeurópskych národov

[cit. 7. 4. 2018]. Dostupné na internete: https://www.monitoringdivadiel.sk/recenzie/recenzia/alegorickyobraz-sucasneho-slovenska/.

${ }^{19}$ Pozri ULIČIANSKA, Z. Sága rodu Esterházyovcov. In Monitoring divadiel na Slovensku. [online]. [cit. 7. 4. 2018]. Dostupné na internete: https://www.monitoringdivadiel.sk/recenzie/recenzia/saga-roduesterhazyovcov/ a BEŇOVÁ, J. Najlepšia značka na trhu. In kød, 2017, roč. 11, č. 2, s. 17 - 22. 
boli tvorcami obesení ako prázdni a zbabelí, teda zbytoční jedinci, kým ostatní umreli za vel'ké idey. Muži reprezentovali neschopnost', ženy ostali žit' d'alej ako nositel'ky nádeje.

Aj v inscenácii Projekt 1918 (SND, 2018, réžia Michal Vajdička) sa stretávame s premenou politicko-spoločenských usporiadaní a s prehrou mužov. Dejiny tu boli ukázané ako deje sprevádzané nekončiacim marazmom, smrtou a bezútešným generačným pohl'adom. Generačná neschopnost’ posúvat' d’alej odkazy otcov a predkov evokovala síce zmenu, no devolučnú. Boj za hodnoty, ktoré si osvojila EÚ, teda prebiehal aj v minulosti, no z perspektívy divadelníkov sa po tomto boji dostavovali iba malé či krátkodobé výhry.

Rodáci Valérie Schulzovej a Romana Olekšáka (SND, 2017, réžia Tilmann Kőhler) sa od spomenutých inscenácií líšia tým, že priniesli tradičný model existenciálnej hry (uzatvorenie v spoločnom priestore s hrozbou kataklizmy) s novodobými postavami: ženou, ktorú znepokojujú škodlivé jedy, skorumpovaného starostu (niekdajšieho člena ŠtB a neskôr SIS), extrémistu, slovenského homosexuálneho migranta prenasledovaného komunistickým režimom. ${ }^{20}$ Inscenácia sa v tézach a frázach vyjadrovala k vážnym problémom - „,k migrantskej kríze, boju s totalitnými zločincami, nebezpečenstvu neonacizmu, homosexualite, xenofóbii, k obavám z islamizmu“21. Sama divadelne reprezentovala však len to, čo chcela kritizovat’ - traumu a krízu, neschopnost’ nazerat na problémy $\mathrm{v}$ ich jadre s istou víziou konštruktívnosti. Naša nátura 21. storočia bola tradične vybudovaná z neznášanlivosti, škriepok a nadávok jedného na druhého. Moderné (rozumej, aktuálne platné) konštruovanie národnej (slovenskej) či európskej identity, ktorá sa preukázala v postojoch zistených aj EVS, sa na javiská slovenských divadiel nepodarilo priniest'.

Podobné dramatické konštrukcie, tematicky miestami divergentné, nastol’ujúce tému politickej zodpovednosti a právneho štátu, priniesli inscenácie hry Pavla Weissa Zo života l’udstva (SND, 2016, réžia Dino Mustafić) či Laca Keratu Dobro (DAB Nitra, 2017, réžia Svetozár Sprušanský), príp. Jiřího Havelku Elity (SND, 2017, réžia Jiří Havelka a kol.). Išlo o paralely socialistických, postsocialistických, ale aj v demokraciách fungujúcich európskych praktík. Napríklad, ako sa možno dostat na vrchol politických a mocenských štruktúr, využit justičnú nepostihnutel’nost’ korupcie elít, či nachádzat’ medzery v štátnom a právnom systéme pre dosiahnutie vlastného prospechu. V Elitách podla kritičky Sone Šimkovej „vyrástli oligarchovia, súčasné elity. Nie je t’ažké uhádnut', že okrem Babiša išlo o J. Širokého, generála Lorenca i literárnu hviezdu Jozefa Banáša. (...) Ked’že k závratnému majetku aktéri Elít prišli až za bezbrehej mečiarovskej privatizácie, v legislatívnom vákuu, a sú dodnes justíciou nepostihnutel'ní, v konečnom dôsledku plačeme nad rozliatym mliekom. ${ }^{\text {22 }}$ Dobro ironicky a metaforicky tematizovalo našu malost’ a výsmech Slováka, ktorý sa stane tvárou slovenského predsedníctva v Bruseli. Hlavná postava, Dobroslav, mal však jeden nedostatok - už od narodenia mu bolo do vienka dané naivné dobro ako orien-

${ }^{20}$ Bližšie pozri ŠMATLÁKOVÁ, L. Slovač, národ krkavčí? In Monitoring divadiel na Slovensku. [online]. [cit. 7. 10. 2017]. Dostupné na internete: https://www.monitoringdivadiel.sk/recenzie/recenzia/slovacnarod-krkavci/.

${ }^{21}$ MIŠOVIC, K. Nadávky publiku spod Tatier. In kød, 2017, roč. 11, č. 7, s. 13 - 18.

22 ŠIMKOVÁ, S. Paralelné životy elít. In Monitoring divadiel na Slovensku. [online]. [cit. 8. 10. 2017]. Dostupné na internete: https://www.monitoringdivadiel.sk/recenzie/recenzia/paralelne-zivoty-elit/. 


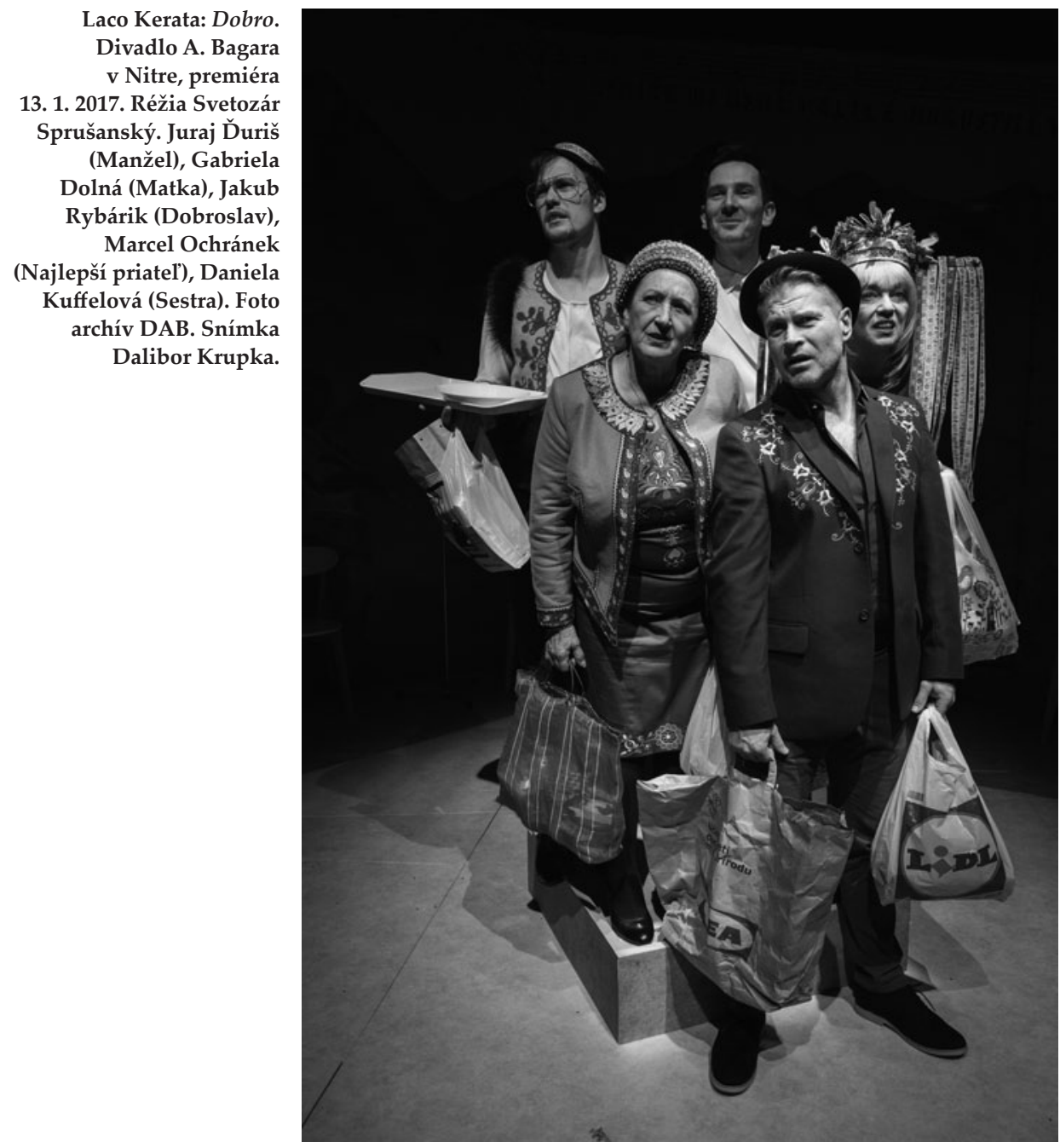

tačná hodnota, a tak nezvládne prirodzené zákulisné tlaky, ziskuchtivé triky a byrokratické nuansy. Nedokáže sa prispôsobit’ európskym štandardom a praktikám sprevádzaným novou rétorikou, za ktorou sa skrývajú staré riadiace mechanizmy moci a manipulácie. Je to obraz temnej a smiešnej budúcnosti nášho človeka, neschopného vyskočit zo začarovaných kruhov. Podobnú tému nastolila aj inscenácia Náš človek (Divadlo Astorka Korzo '90, 2018, réžia Ján Luterán), ktorá priniesla nového hrdinu - životaschopného prezliekača kabátov, ktorý v nových podmienkach len náhodou (teda nie vymožením spravodlivosti) doplatí na svoje machinácie, mafiánske sklony, nečestnost’ a nakradnutý blahobyt. Je však otázne, či možno tieto inscenácie považovat' za obhajobu demokracie, slobody, práva, resp. boj za tieto hodnoty a ich presadzovanie. Nevyznievajú ako ostrá satira, ani nevystupujú v mene hájenia spomenutých európskych hodnôt. Pôsobia skôr ako smiešna fraška, tragikomédia alebo 
lahká irónia či úškrn nad vel'kými témami dneška, ktoré sú spoločné pre európske spoločenstvo, a stavom, v akom ho nachádzame. ${ }^{23}$

Do skupiny politicky ladených a hovoriacich o európskych verejných hodnotových pilieroch, akými sú demokracia, právny štát, sloboda, sloboda prejavu, bezpečnost' občanov, by sme mohli zaradit’ napr. inscenácie Sofoklových hier Antigona (SND, 2018, réžia Ondrej Spišák) a Elektra (Divadlo Astorka Korzo '90, 2017, réžia Lukáš Brutovský). V Antigone vodca, král' Kreón, koná zásadné rozhodnutia nepriznajúc, že má o ich správnosti vážne pochybnosti. Následkom týchto rozhodnutí však vymiera jeho rod, zatial' čo chór sa zmenil na parlament mužov v čiernych oblekoch a dám vo vyzývavých kostýmoch. Už nemá potrebu byt’ sudcom alebo zrkadlom spoločnosti, prijal polohu dvojitej hry. Zdá sa, že téma tragických následkov neuvážených rozhodnutí mocných - či už volených alebo dosadených reprezentantov stráženia spravodlivosti, ktorí sa vzpierajú uznat', že nestoja nad Bohom či novým pokolením - je nadčasová a pre divadelnú aktualizáciu istej hodnotovej štruktúry spoločnosti vd’ačná. O Elektre a jej tematickej inscenačnej interpretácii sa kritik Milo Juráni na festivale Dotyky a spojenia v Martine vyjadril, že dôležitý je pohl'ad tvorcov na samotnú postavu Elektry, ktorá sa stáva obetou. Obetou režimov, ktoré sa nad ňou striedajú, ktorým dopomáha, ale nakoniec ostáva úbohá sama pred domom, aby sa situácia ešte miliónkrát v histórii zopakovala. ${ }^{24}$ Akoby tragika a tragédia číhali naokolo, vel'mi blízko, a divadlo tento pocit z našej súčasnej doby začína ohlášat'. Akoby pred nami stáli opät možné rady obetí, čo zatažia l'udský údel, pretože sme si právo aj spravodlivost’ zrelativizovali a nahradili ich právom na pomstu i obete.

Tragický moment, spätý s extrémistickým naladením človeka 21. storočia, predstavoval východiskový tematický bod aj pre inscenácie Natálka (SND, 2017, réžia Matúš Bachynec) a Vojenské meno Rama (Divadlo Pôtoň, 2017, réžia Sashko Brama) ${ }^{25}$.

Inscenácia-projekt Natálka bola edukačným a mobilným projektom SND. ${ }^{26}$ Išlo o divadelnú rekonštrukciu minulých, no nie tak dávnych udalostí z Českej republiky, s presahom k prítomnosti, aj tej na Slovensku. V roku 2009 štyria mladíci podpálili dom obývaný rómskou rodinou. Následky ničivého požiaru si odniesla malá Natálka. Inscenácia prináša postavu Natálkinej matky niekol'ko rokov po útoku. Vidíme jej materskú a l’udskú (humánnu) silu, odhodlanie a lásku, ale spoznávame aj postoje a motivácie páchatel’ov, ktoré môžu byt’ ukryté za takýmto činom. Proces tejto kauzy sa v spoločenskom kontexte stal skúškou súdnej moci, no aj humanity

${ }^{23}$ Podobne Rivers of Babylon (SND, 2016, réžia Diego de Brea) ako western, kde sa z kuriča stane vekslák, z veksláka mafián vzbudzujúci strach a rešpekt, a tak prenikne do najvyšších politických štruktúr za piesne What a Wonderfull World.

${ }^{24}$ JURÁNI, M. Kritická platforma Dotyky a spojenia, príloha časopisu kød, 2017, roč. 11, č. 7, s. 50.

${ }_{25}$ Túto inscenáciu zarad’ujeme do kontextu štúdie, pretože bola zakrátko po premiére pozvaná dramaturgiou SND hostovat' do Modrého salónu.

${ }^{26}$ Podobne ako inscenácia Dubček (Divadlo Aréna, 2018, réžia Michal Skočovský), venovaná mladým divákom, v ktorej mladí herci meditujú nad témou normalizácie, komunizmu, socializmu, socializmu s ludskou tvárou a pod., avšak v ideologicky jednostranne poňatej interpretácii, ktorá o Alexandrovi Dubčekovi a dobe, v ktorej žil, prinesie len tézy. Ovel’a politickejšie boli inscenácie Mier chatrčiam, vojnu palácom (SND, 2016, réžia Ingrid Timková), odhalujúca mechanizmus fungovania moci a nelútostne vyrátavajúca zbytočné náklady na živenie nefunkčného štátneho aparátu, ktorý nerešpektuje liudské práva a slobody a nectí si svojich občanov, a Kabaret normalizácia alebo Modlitba pre Martu (SND, 2017, réžia Matúš Bachynec), ktorá bola nasmerovaná v explicitné vyjadrenie ochrany l’udských práv, slobody a slobody prejavu. 


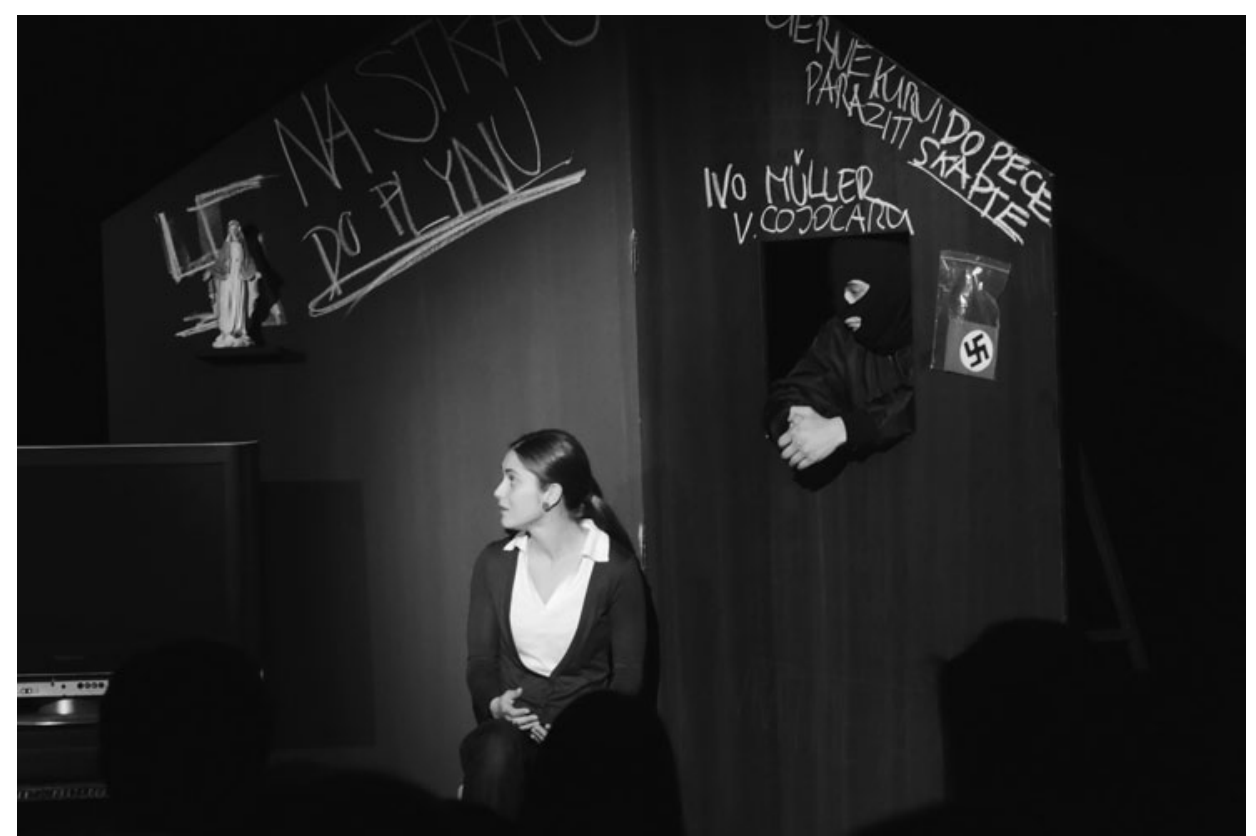

Natálka. Slovenské národné divadlo, premiéra 5. 12. 2017. Réžia Matúš Bachynec. Judit Bárdos, Marek Koleno. Foto archív SND. Snímka Alena Klenková.

a l’udskosti. V rovnakom duchu sprostredkovali inscenátori tému mladým študentom. ${ }^{27}$

Popri témach rasizmu, extrémizmu, holokaustu, totality sa v projekte stretávame so snahou tvorcov zamerat' pozornost' mladého diváka na l'udskost', humanizmus, demokraciu, toleranciu, suplovat’ oslabené znalosti historických kontextov. Nemenej zaujímavé je to, čo inscenátori až tak nezdôrazňovali, no samotná téma ako príbeh zo života to do inscenácie vniesla: manipuláciu so slovami, prácu súdnej moci vo vzt̉ahu k mediálnemu a politickému tlaku, ktorý dokáže spôsobit i to, že sa z obetí stávajú vinníci a $\mathrm{z}$ vinníkov obete. Podobne zameraná bola aj inscenácia hry Kopanec súčasných nemeckých autorov Gesine Schmidt a Andres Veiel (DJP Trnava, 2018, réžia Viktor Kollár) o brutálnej vražde 16-ročného chlapca, ktorého zabili traja kamaráti. Predsudky, fóbie a nenávist’ nemajú v tomto príbehu reálny základ. Strach z iného je silnejší než konkrétny dôvod na šikanovanie, pomstu či agresívny prejav odplaty, takže obet’ou sa môže stat' ktokol'vek bez vlastného pričinenia. Trnavské divadlo na svojej webovej stránke uverejnilo obsah, za ktorým sa črtá dramaturgia tém, ako sme ju artikulovali v úvode štúdie: „Hra je vystavaná ako sled výpovedí vrahov, ich rodičov, matky obete a svedkov udalosti. V hre sa odhal'ujú skryté korene l’udskej agresivity a nevybúrenej nenávisti, ktorú si predávajú rodiny z generácie na generáciu. “28 A hoci prieskum EVS, zvolený ako referenčný pre potreby tejto štúdie, nepreukázal

${ }^{27}$ Hru Natálka si po študentoch môže pozriet’ aj verejnost'. [online]. [cit. 20. 5. 2017]. Dostupné na internete: https://kultura.pravda.sk/divadlo/clanok/420700-hru-natalka-si-po-studentoch-moze-pozriet-aj-verejnost/.

${ }^{28}$ Dostupné na internete: http://www.djp.sk/predstavenie/kopanec. [cit. 21. 5. 2017]. 
mimoriadne xenofóbne či radikálne nastavenia slovenskej spoločnosti, dianie u nás, ale aj v okolitých krajinách nám približne rok po premiére Natálky a Kopanca ukazuje inú tvár. Funkciou divadla je byt angažovaným médiom, to znamená, aj v čase zdanlivého pokoja pripomínat', čo by sa mohlo stat', na aké hodnoty sa nemá zabúdat', ale naopak, treba ich verejne prízvukovat.

Rovnako Vojenské meno Rama hostujúcich ukrajinských tvorcov ${ }^{29}$ prinieslo tému násilia a iracionálneho, možno radikalizmom ovplyvneného útoku na mladé dievča, ktoré však v inscenácii prerástli (metaforicky aj doslovne) do vojenských konfliktov a frontov, kde umierajú vojaci. Inscenácia Vojenské meno Rama je o osude jednej ženy, ale aj o zlyhaní systému, o zlyhaní štátu. Je obrazom krajiny, kde prestávajú platił zákony, kde sa policajti správajú rovnako ako zločinci ${ }^{30}$, a preto je jediným východiskom šírit’ na individuálnej báze opačné hodnoty - lásku, toleranciu. Základom je príbeh dievčiny, z ktorej sa po násilnom útoku na ňu stane dobrovol'níčka s malou gitarou ukulele. ${ }^{31}$ Hrá jednoduchú melódiu a spieva uspávanku o dobrote jedným z najstarších jazykov sveta. Od začiatku vojny znie táto pesnička vo vojenských nemocniciach a na fronte: „Teraz musí zniet’ v divadle. Aké sú možnosti umenia vo svete divokej a drsnej reality, kde neexistuje pravda a vítazstvo, vo svete, kde všetky slová stratili zmysel? Dúfame, že sa nám prerozprávaním jej životného príbehu podarí krok za krokom vytvorił’ prúd, ktorý nás zavedie spät k pôvodu l'udstva“32, píše sa $\mathrm{v}$ bulletine $\mathrm{k}$ inscenácii.

Koreňom násilia sa venovala aj režisérka Sláva Daubnerová v autorskom projekte Solo lamentoso (2016, réžia Sláva Daubnerová) a inscenácii Spievajúci dom (SND, 2017, réžia Sláva Daubnerová ) o kauze zo Štúrova. Tá sa vd’aka jej medializácii a tiež neriešeniu zo strany kompetentných orgánov stala otvoreným občianskym konfliktom medzi Evou N., ktorá si niekol'ko rokov bez prestania nahlas púštala opernú áriu, čím znepríjemňovala život svojim susedom, a obyvatel'mi jednej štúrovskej ulice. Títo prevzali spravodlivost’ do vlastných rúk a Eve N. vykonávali svoje malé pomsty a odplaty v snahe sa jej ako susedky zbavit. Obe strany pritom bojovali za rovnaké hodnoty - toleranciu, uznanie práva a ticho. Inscenácia ako jedna z mála korešpondovala s témou práva na osobnú slobodu i slobodu prejavu na osi verejné - súkromné a spät, pričom upozorňovala na nesystémovost’ nastavení pri uplatňovaní takéhoto práva občana vo verejnej sfére každodenného života.

Zaujímavú vzorku tvoria inscenácie, ktoré paradoxne už názvom vzbudzujú negatívne konotácie či obsahové/tematické náplne (Túžba po nepriatelovi, Nevina, Strach, Podvolenie, Nehoda, Fóbie, Zjavenie (hrobárova dcéra)). Väčšina je z repertoáru SND a vznikla aj vd’aka dvom sezónam, ktoré boli venované slovenským hrám inscenovaným zahraničnými režisérmi a hrám napísaným pre SND zahraničnými autormi.

\footnotetext{
${ }^{29}$ Divadlo uviedlo inscenáciu v Modrom salóne SND, 17. 3. 2017.

${ }^{30}$ DITTE JURČOVÁ, I. - ANDREJČÁKOVÁ, E. Hercovi v Bátovciach zajtra môže príst̉ povolávací rozkaz. [Rozhovor s Ivetou Ditte Jurčovou]. [online]. [cit. 4. 7. 2018]. Dostupné na internete: https://kultura. sme.sk/c/20474254/hercovi-v-batovciach-zajtra-moze-prist-povolavaci-rozkaz.html.

${ }^{31}$ Vojenské meno Rama - Slovenské Tour. [online]. [cit. 14 3. 2018]. Dostupné na internete: http://www. poton.sk/aktuality/vojenske-meno-rama-slovenske-tour/.

${ }^{32}$ Vojenské meno Rama : Divadlo Pôtoň. [Bulletin k inscenácii]. Bátovce : Divadlo Pôtoň, 2017, nestránkované.
} 


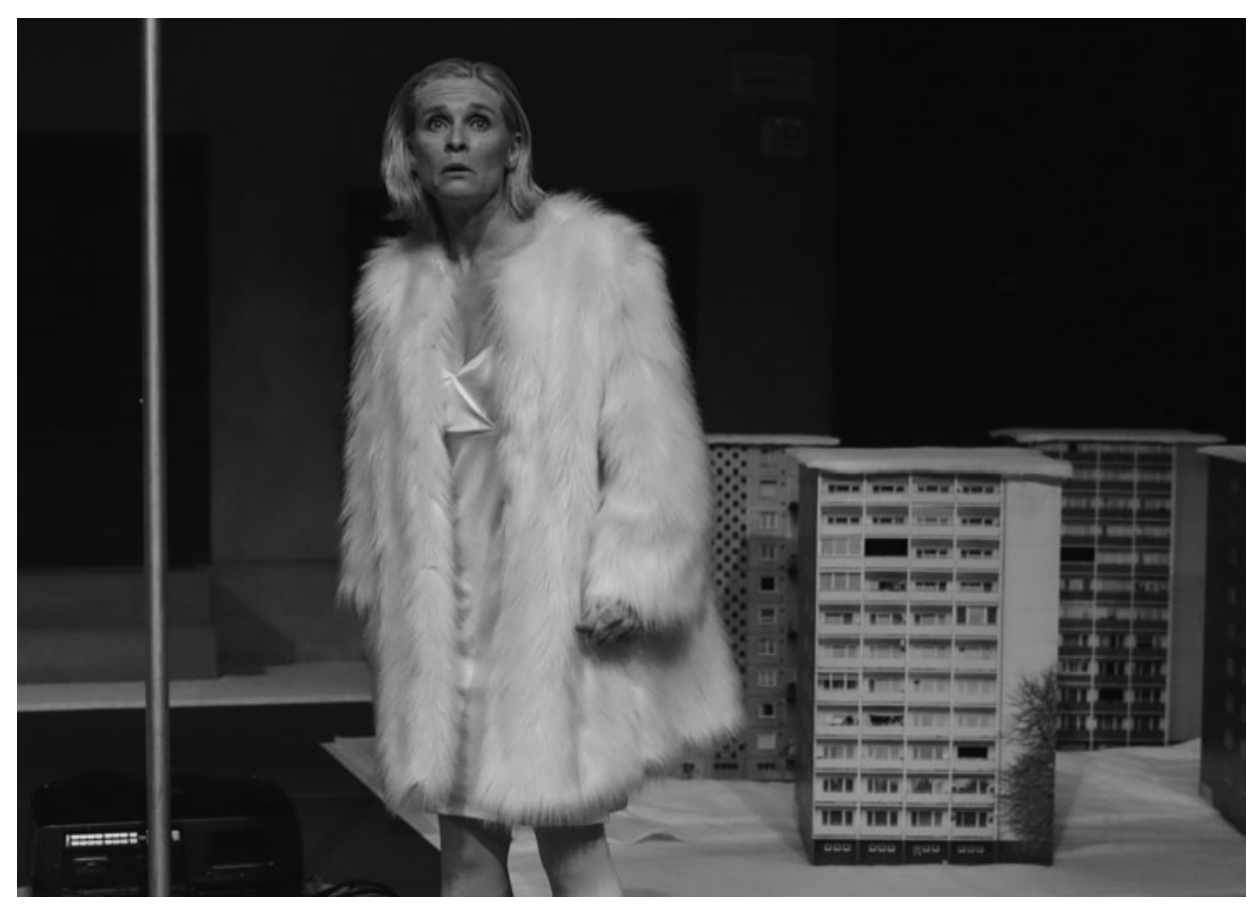

Sláva Daubnerová: Spievajúci dom. Slovenské národné divadlo, premiéra 27. 5. 2018. Réžia Sláva Daubnerová. Ingrid Timková (Eva N.). Foto archív SND. Snímka Ctibor Bachratý.

Túžba po nepriatelovi Bernharda Studlara (SND, 2017, réžia Ján Luterán) je o vyhasnutej vášni a sexe medzi mužmi a ženami, o životnej frustrácii a neurčitej existenciálnej naštvanosti, o nespokojnosti ústiacej do výbuchov, ktoré si cielene hladajú svoju obet. Je to tematizácia špirály narastajúceho násilia, kde dvojice reprezentujú spoločensky zásadné hrozby - občianske vojny, ktorých politickým a ekonomickým príčinám už nikto nerozumie; masové nepokoje ako následky personifikovaných osobných frustrácií a vykonštruovaných nepriatel'ov, na ktorých sa môžeme spokojne vŕšit; neurózy dneška vedúce $\mathrm{k}$ chaosu, rozkladu a útoku. Nevina nemeckej dramatičky Dey Loher (SND, 2016, réžia Eduard Kudláč) priniesla tému našej túžby po vyvinení sa, po štastí, po zmysle našej malej existencie, o potvrdení našich snov i ambícií. Rad bizarných postáv tu vystupuje pred divákov so svojou vnútornou či predstieranou vinou a túžbou po odpustení, po nevine, po záchrane našich duší a aj životov súčasných l'udí. Strach Petra Lomnického (SND, 2016, réžia David Jařab) zase akcentoval pocit strachu (postdramaturgia pocitov) vo forme novodobých fóbií a odkazoval na akúsi apokalyptickú víziu katastrofy, ktorá nás ponorí do tmy a začne vyvolávat’ dávne atavizmy, úzkosti a paranoje pochádzajúce z našej neistoty a straty riadiacej pozície nad zemou i vesmírom, pričom únik je takmer nemožný (lebo uniknút prapodstate l’udí nie je možné).

Podvolenie podla knihy Michela Houellebecqa (Divadlo Aréna, 2016, réžia Marián Amsler) prináša ukážkový príklad postavy dnešného vyhoreného a deprimovaného intelektuála ako reprezentanta západnej vzdelanej kultúry. Postupne diagnostiku- 


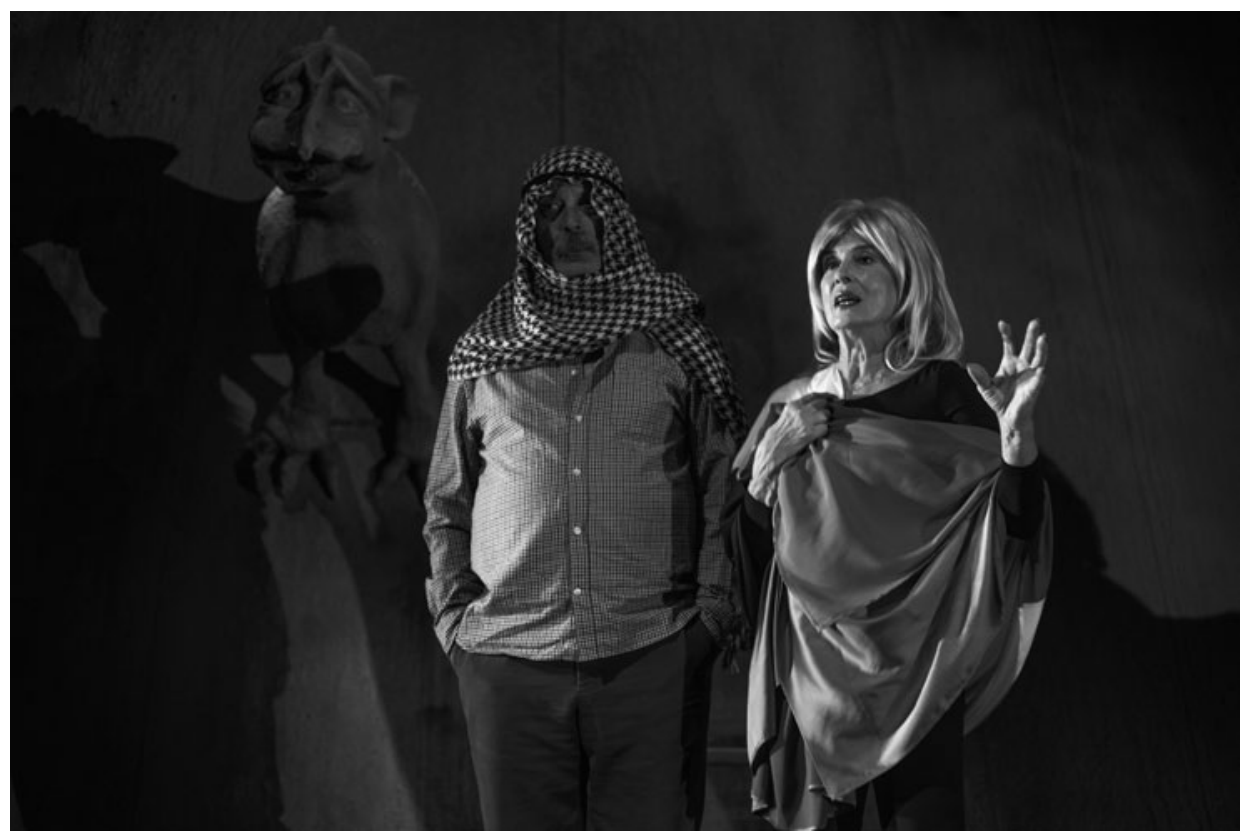

Michel Houellebecq: Podvolenie. Divadlo Aréna, Bratislava, premiéra 10. 11. 2016. Réžia Marián Amsler. Štefan Kožka (Mohamed Ben Abbes), Zuzana Kocúriková (Marine Le Penová). Foto archív Divadla Aréna. Snímka L’uboš Kotlár.

jeme jeho stavy smerujúce k podvoleniu sa (auto)deštrukčnej sile - tichej islamskej expanzii, ktorá pomaličky ovláda starý kontinent. ${ }^{33}$ Profesor literatúry na sorbonskej univerzite François je akoby metaforou súčasnej unavenej Európy a konca jej kultúrnych dejín založených na anticko-krestanskej tradícii. Tam, kde niet Boha, pevných hodnôt, funkčných vztahohov, politickej korektnosti a kde peniaze prevládajú nad l'udským životom i vzdelaním, musí prísţ zásadný zlom. Bude ním pohltenie a nahradenie našej kultúry inou? Nuda, strnulost', bezbrehost’ a neustále hrozby extrémizmu, ktoré Françoisa obklopujú, vedú k jeho dobrovolnému podvoleniu sa - konvertovaniu na islam s perspektívou nových istôt a finančného profitu. Je však možné vzdat' sa samých seba, vlastného presvedčenia, identity a tak sa zachránit? Túto tému d’alej rozvíja inscenácia hry Rolanda Schimmelpfenniga Na druhom brehu (DJP, 2018, réžia Viktor Kollár), ktorá kladie otázky o migrácii a výmene európskych a mimoeurópskych pozícií. Európske hodnoty a systém sa aj pod vplyvom tých „z druhého brehu“ rozpadajú a možno je len otázkou času, kedy sa ocitneme na druhom brehu my - jednotlivec i spoločenstvo.

${ }^{33}$ Podobnú tému sme mohli postrehnút aj v inscenácii zloženej z dvoch častí (adaptácia dvoch filmových diel) Úpadok amerického impéria, Invázie barbarov (SND, 2015, réžia Michal Vajdička), kde hlavná postava amerického intelektuála ako záruky istej hodnotovej orientácie je vystavená rozčarovaniu z rýchlych civilizačných a generačných posunov, hrozbe úpadku západnej civilizácie (feminizmus, AIDS, mediálna moc, pokrytectvo, homosexualita, nuda atd') a hrozbe invazívnej barbarskej zmeny (pristahovalci z tretích krajín). Obava z barbarskej invázie korešponduje s predsudkom nenávratnej zmeny či rozkladu konštituovaných a ustálených západných hodnôt. 
S apokalyptickým rámcom pracuje aj Klimáčkovo Zjavenie (hrobárova dcéra) (SND, 2017, réžia Vladimír Serre). V jednoduchej dedine v horách skromne žije rodina. Matka je bývalá ruštinárka, ktorá kladie vence k pomníku padlých ruských hrdinov (až kým nepríde na to, že ide o celkom iné, židovské obete) a upratuje chaty po zbohatlíckych radovánkach. Otec príde o prácu a chodí sa pred hanbou aj manželkou radšej skrývat' na cintorín. Dcéra trpiaca epileptickými záchvatmi má predtuchy, vidí zjavenie biblických postáv Jozefa a Márie, budúci zat’ je prívržencom a vodcom extrémne orientovanej skupiny Karpatské vlky. Tieto postavy sú len trochu ironickým rámcom, podkladom pre nosnú tému. Ňou je pocit ohrozenia a nutnosti bránit’ staré hodnoty a svoj malý či rodinný svet, hoci dávno poznačený tým, že sa v takom prostredí a podmienkach dlho prežit nedá. Rozhodujúcim momentom je reálny príchod ohlasovaného zjavenia Božieho páru s novorodencom uprostred zimy, v čase Štedrého večera. Podobne ako pred 2000 rokmi, Svätá rodina prichádza medzi vlastných, a vlastní ju neprijali. Zázrak (zjavenia, na ktorých sa hrobárova rodina aj vzhladom na sociálnu krízu pretrvávajúcu v zabudnutých lazoch snažila zarobit’ peniaze prostredníctvom uznania ich dediny ako pútnického miesta v najvyšších cirkevných kruhoch) sa dostavil do Bohom opustenej horskej dediny v podobe sýrskych migrantov. Strach bol silnejší ako l'udskost', a tak musela táto rodina ako metafora krestanskej hodnoty pokračovat’ d’alej v púti uprostred snehových závejov, ktoré novorodenec ako symbol nového zákona, morálky a hodnôt postavených na láske k blížnemu a Bohu asi len tažko prežije.

Divadelný kritik a estetik Miroslav Ballay v recenzii inscenácie uvádza: „Autor [Viliam Klimáček - pozn. E. K.] spája aktuálnu tematiku utečeneckej krízy s objavením sa vystrašených a umorených migrantov, ktorí narušili stereotypný chod jednej rodiny a tiež dediny. Jedine hrobárova dcéra $\mathrm{k}$ nim prejavuje patričnú dávku empatie, ako aj krest’anskej povinnosti úcty k blížnemu. Doslova v predvečer Vianoc ich tajne ubytuje vo svojom dome v garáži. Hrobárova rodina evidentne stráca kontakt so skutočnost’ou - hrobár sa rozpráva na cintoríne s nebožtíkmi, prihovára sa im, prípadne ich komentuje, mladý policajt sa angažuje v pochybnej braneckej družine, hrobárova žena nostalgicky ospevuje totalitné časy bývalého komunistického režimu, atd'. (...) Inscenačný tím všemožne upozorňoval, ako sa Slovákom, poznačeným rôznymi historickými skúsenostami i kultúrnymi tradíciami, nedarí prekonávat’ strach z migrantov prichádzajúcich na naše územie. “" ${ }^{34}$

Je zaujímavé, že mnohé zo spomenutých inscenácií prinášajú tému strachu z iného, ktorý aj presne identifikujú. Už ním nie sú neslobodné totalitárne systémy a ideológie, ktoré poznáme z minulosti (napr. komunizmus), ale sú nimi migranti a vzrastajúca aktivita extrémistických či náboženských, najmä moslimských skupín. V tomto smere sa teda spoločensky, politicky i mediálne nastol'ovaná agenda stretla s jej divadelnou ozvenou. Napriek tomu, že sme na Slovensku nezaznamenali prílev utečencov ani radikálne teroristické a ozbrojené útoky (rasovo či nábožensky motivované), divadlo reagovalo na európsky pocit a stav ohrozenia, pričom tento pocit nespochybnilo ako neodôvodnený.

${ }^{34}$ BALLAY, M. Opakované zjavenia ako anticipácia krízy (?). In Monitoring divadiel na Slovensku. [online]. [cit. 10. 2. 2018]. Dostupné na internete: https://www.monitoringdivadiel.sk/recenzie/recenzia/opakovane-zjavenia-ako-anticipacia-krizy/. 


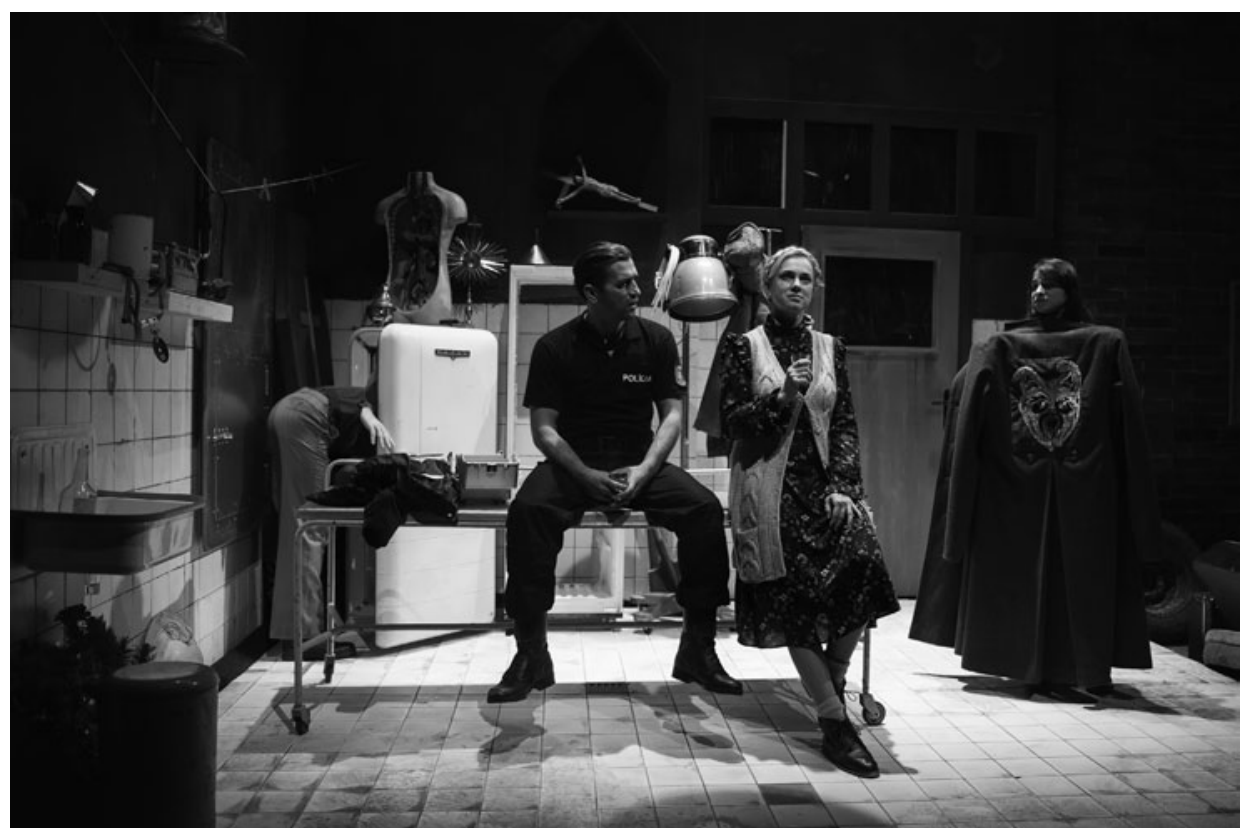

Viliam Klimáček: Zjavenie (hrobárova dcéra). Slovenské národné divadlo, premiéra 4. 11. 2017. Réžia Vladimir Serre. Robert Roth (Otec), Milan Ondrík (Laco), Monika Hilmerová (Matka), Monika Potokárová (Dcéra). Foto archív SND. Snímka Róbert Tappert.

Reakcia súčasného slovenského divadla v mnohom pripomína to, čo do odborného diskurzu prinieslo už zlomové dielo Georga Büchnera Woyzeck. To, čo sa tematizuje, je patológia l'udskej duše a svedomia, rozvrat, ktorý spoločnost' desí a zároveň fascinuje a s ktorým, ba ani s ambivalentnostou svojho postoja k nemu, sa nedokáže lahko vyrovnat'. Večný antagonizmus chaosu a poriadku, ktorý konštituuje európsku kultúru, stratil svoj bezpečný záchytný bod v myšlienkovej štruktúre sveta, kde malo miesto aj niečo transcendentálne (napr. inštitút Boha či vyššieho poriadku), na čo sa odvolávajú naše skutky a na základe čoho dávame našim životom zmysel. ${ }^{35}$ No kým revolucionár Büchner v 19. storočí naznačoval zmenu (kdesi v podzemí sa to otriasa a je len otázkou času, čo a v akej sile vyjde na povrch), súčasné divadlo na Slovensku tieto otrasy už umiestnilo na zemský povrch, do centra spoločenských (ba dokonca medzinárodných) aj medziludských vzt’ahov, v podobe množiacich sa konfliktov. Vtedajšie postavy vedeli, že žijú v čase prechodu, a teda nebudú žat’, dnešné postavy akoby hovorili: Žijeme v čase prechodu, ale žat budeme neúrodu.

Medzi bezpečné záchytné body v myšlienkovej, ale aj praktickej hodnotovej štruktúre európskeho sveta patrila predovšetkým rodina. Súčasná dráma a divadlo ostatných dvadsiatich rokov priniesli jej zmenený model i fungovanie. Rodina viac nie je

${ }^{35}$ Bližšie pozri VEDRAL, J. Divadlo disensu v tekuté epoše dědiců Johanna Christiana Woyzecka. In Má mat' divadlo zmysel? Zborník referátov z VIII. medzinárodnej banskobystrickej teatrologickej konferencie v cykle DNES A TU. (Ed. Andrej Matašík). Banská Bystrica : Akadémia umení v Banskej Bystrici, Fakulta dramatických umení, 2010, s. 58. 
scelenou bunkou, oslabila sa pozícia otca, deti neprejavujú úctu k rodičom. Toto obdobie rodinných rozkladných reprezentácií však v súčasnosti ústi ešte d’alej. Už nie je také zaujímavé sledovat' zmenené hodnoty vo vzt’ahu manželov, rodičov a detí, ktoré smerovali najmä k artikulácii znecitlivenia či nástupu agresivity (psychickej alebo fyzickej). $V$ takto zachytených rodinných modeloch sme napriek posunom ešte stále mohli vnímat’ to, čo rodinu drží pokope, či už to boli láska, nenávist́, alebo tajomstvo obsahujúce negatívne až sebadeštrukčné konotácie. Súčasné slovenské divadlo prináša správu o zmenenom fungovaní rodiny, ktorá sa viac nemôže spoliehat na stabilné záchytné či záchranné rodinné body, pretože tieto už nenachádzajú oporu v samotnej životnej hierarchii postáv.

Hra Gerharta Hauptmanna Pred západom slnka (SND, 2018, réžia Michal Vajdička) bola inscenátormi interpretovaná ako príbeh dobre situovaných detí, ktoré spoločensky popravia svojho otca, oberú ho o majetok i svojprávnost', a pre vlastné sebectvo ani netušia, prečo ich otec končí tragicky. Podobne inscenácia Fanny a Alexander (SND, 2016, réžia Marián Amsler) problematizovala rigoróznost’ rodinnej morálky. $\mathrm{V}$ podstate korešpondujúc s umiernenejšími postojmi obyvatelov Slovenska a ostatných krajín EÚ, ktoré sa preukázali v rámci EVS, už nenahliadala na fungujúcu rodinu z perspektívy krestanskej morálky, ale z perspektívy vol’ného (kedysi možno amorálneho) modelu fungovania, v ktorom rodinní príslušníci dokážu harmonicky zabezpečit’ pre deti (našu budúcnost') slobodné a radostné detstvo, aj napriek drobným mravným úpadkom. ${ }^{36}$

Najliberálnejšie hodnotové postoje však priniesla trojica inscenácií pod spoločným názvom Morálka 2000+ (SND, 2016, réžia Alena Lelková, Júlia Rázusová, Kamil Žiška). Tradičné (krestanské) etické postoje boli preverované v kontexte súčasného trendu uvolňnovania ich výkladu, ale aj v kontexte nástupu nových technológií, ktoré zatial' nie sú viazané nijakou spoločensky ukotvenou etikou. Konflikt v inscenáciách vyplýval z rozporu prirodzeného chodu vecí a vedeckého pokroku. Témy korešpondovali aj s mediálnym diskurzom a ním nastol’ovanými agendami, ako sú napr. potláčanie prirodzeného biorytmu žien a asistovaná reprodukcia (resp. diet’a zo skúmavky), žena a diet’a ako predstava kompletnej rodiny, estetická medicína a vedecké predlžovanie života bez ohl'adu na prírodné zdroje, genetické úpravy jedincov, eutanázia či akceptovanie dobrovol'nej samovraždy. Je zjavné, že Morálka 2000+ reagovala na tendenciu, ktorú potvrdil aj EVS, a to potrebu udržatel'nosti rodiny a práce v živote človeka, avšak za predpokladu uvol’ňovania vzt’ahu medzi manželstvom a zakladaním rodiny, resp. vnímania manželstva a doterajšej rodinnej hierarchie a rozdelenia "rodinnej moci“ ako zastaraných inštitúcií či zriadení.

Ak sa pozrieme na spomenuté inscenácie cez prizmu otvorenej hypotézy, že vnútorná, scelená európska entita alebo identita je z pohl'adu divadelného umenia len pomerne hmlistým konceptom, zistíme, že súčasné slovenské divadlo naozaj ostáva médiom, reagujúcim najmä na jednotlivosti a ich premeny. Predstava takejto európskej entity alebo identity je síce formálne zastrešená vonkajšími štruktúrami a poriadkom, no divadlo na ňu nahliada vo svojej pluralite skôr ako na mozaiku poskladanú

\footnotetext{
${ }^{36}$ Na fenomén sociálnych fóbií, strachu zo záväzkov či vztahov ako novodobej formy spolunažívania formou vzájomného vyjednávania nadviazali tiež inscenácie Fóbie (Slovenské komorné divadlo Martin, 2018, réžia Lukáš Brutovský), Pl’úca (Divadlo Astorka Korzo '90, 2018, réžia Michael Vyskočáni), Znovuzjednotenie Kóreí (Štátne divadlo Košice, 2018, réžia Júlia Rázusová).
} 
z pevne ohraničených častí, ktoré až následne tvoria celok - obraz, príbeh, spoločný pocit, prípadne skúsenost' atd'. Status europeanizmu v tomto smere nezohráva až takú dôležitú úlohu ani v nastol'ovaní tém (dramaturgii tém), ani v ich interpretácii. Dokonca ani postoje obyvatel'ov EÚ vo vzt’ahu k dôležitým oblastiam l'udského života vždy nekorešpondujú (často práve naopak) s tým, čo ponúka naše divadlo, hoci na redukovanej inscenačnej a časovej vzorke.

Zaujímavé však je, že všetky inscenácie majú jeden spoločný prvok. Ohláša sa v nich apokalypsa, katastrofa, zatmenie, koniec - koniec sveta ako ho poznáme a príchod čohosi iného, cudzieho, z čoho pocitujeme úzkost'. Tu sa núka otázka, či a čo tým súčasné (slovenské) divadlo anticipuje. Ak aj umelecky tematizuje európske postoje a hodnoty, poskytuje im nedobré konce. Tematizuje/anticipuje teda krízu, ktorej sa nie je možné vyhnút? Alebo naopak, možnú záchranu európskeho sveta stojaceho na anticko-krestanskej kultúre?

\section{REFLECTION OF EUROPEAN VALUES IN CONTEMPORARY SLOVAK THEATRE}

\section{Elena KNOPOVÁ}

The study deals with the identification of a representative sample of topics that have entered the artistic and social discourse through production work in Slovak repertoire theaters over the last three years (2016 - 2018). It gives them an implicit point of view from the perspective of thematic dramaturgy and so-called post-dramaturgy of feelings, as well as from the perspective of European values recorded in current sociological surveys. The author, by comparing the results of the European Values Study, the goals and values represented by the European Union as a community and the topics raised by the Slovak theatre (the so-called established and repertoire theaters), tries to establish whether or not and if so - how, our theater communicates through the reflection of the themes and their interpretation with the attitudes of Slovak and European citizens. For example on the issues such as identity, family, threat, tolerance, Islamization of the old continent, protection of democracy, but also legitimization of traditional values liberalisation.

Príspevok je súčastou riešenia projektu APVV č. 15-0764 Slovenské divadlo a súčasná európska divadelná kultúra - kontinuita a diskontinuita.

\section{LITERATÚRA:}

BAHR, Hermann. Zur Überwindung des Naturalismus. Weimar : VDG Verlag, 2004, 279 s. ISBN 9783897394360.

BALLAY, Miroslav. Opakované zjavenia ako anticipácia krízy (?). In Monitoring divadiel na Slovensku. ISSN 2454-0129. [online]. [cit. 10. 2. 2018]. Dostupné na internete: https://www.monitoringdivadiel.sk/recenzie/recenzia/opakovane-zjavenia-ako-anticipacia-krizy/.

BALLEK, Rastislav. Kritická platforma Dotyky a spojenia, príloha časopisu kød, 2018, roč. 12, č. 7, s. 22. ISSN 1337-1800. 
BEŇOVÁ, Juliana. Najlepšia značka na trhu. In kød, 2017, roč. 11, č. 2, s. 17 - 22. ISSN 1337-1800.

BEŇOVÁ, Juliana. Uzavretost’ a pasivita nezmizli z národnej povahy ani po storočí. In kød, 2017, roč. 11, č. 6, s. 30 - 35. ISSN 1337-1800.

Ciele a aktivity Európskej únie (Zmluva o EÚ). [cit. 13. 6. 2018]. Dostupné na internete: https:// www.lewik.org/term/7496/ciele-a-aktivity-europskej-unie-zmluva-o-eu/.

DITTE JURČOVÁ, Iveta - ANDREJČÁKOVÁ, Eva. Hercovi v Bátovciach zajtra môže príste povolávací rozkaz [rozhovor]. In SME. Kultúra. [online]. [cit. 4. 7. 2018]. Dostupné na internete: https://kultura.sme.sk/c/20474254/hercovi-v-batovciach-zajtra-moze-prist-povolavaci-rozkaz.html.

Hru Natálka si po študentoch môže pozriet’ aj verejnost'. [cit. 20. 5. 2017]. Dostupné na internete: https://kultura.pravda.sk/divadlo/clanok/420700-hru-natalka-si-po-studentoch-moze-pozriet-aj-verejnost/.

KNOPOVÁ, Elena. Európska cena za divadlo 2006 alebo Je skoro nemožné, aby sa špičkové európske divadlo dnes nevyjadrovalo politicky. In Slovenské divadlo, 2006, roč. 54, č. 3, s. 451 - 454. ISSN 0037-699X.

KNOPOVÁ, Elena (ed.). Súčasné slovenské divadlo v dobe spoločenských premien : pohl'ady na slovenské divadlo 1989-2015. Bratislava : Veda : Ústav divadelnej a filmovej vedy SAV, 2017. 368 s. ISBN 978-80-224-1620-7.

Kopanec. Dostupné na internete: http://www.djp.sk/predstavenie/kopanec.

L’udské práva v EÚ. [23. 8. 2018]. Dostupné na internete: http://eu.euroiuris.sk/pre_pedagogov/ ludske_prava_v_eu.

PODMAKOVÁ, Dagmar. Alegorický obraz súčasného Slovenska. In Monitoring divadiel na Slovensku. ISSN 2454-0129. [online]. [cit. 7. 4. 2018]. Dostupné na internete: https://www.monitoringdivadiel.sk/recenzie/recenzia/alegoricky-obraz-sucasneho-slovenska/.

MISTRÍK, Miloš. Slovak Theatre as a European Entity. In KNOPOVÁ, Elena (ed.). Theatre as a Value-based Discourse. Slovak Theatre and Contemporary European Theatre Culture. Bratislava: Veda, 2018, s. 13 - 20. ISBN 978-80-224-1705-1.

MIŠOVIC, Karol. Nadávky publiku spod Tatier. In kød, 2017, roč. 11, č. 7, s. 13 - 18. ISSN 13371800.

Naše európske hodnoty 2017. Komentár k zisteniam slovenskej časti výskumu európskych hodnôt EVS 2017. [Tlačová správa]. [cit. 10. 10. 2019]. Dostupné na internete: http://www.sociologia.sav.sk/cms/uploaded/2786_attach_EVS_SK_2017_tlacova_sprava\%20final.pdf.

ŠIMKOVÁ, Soňa. Paralelné životy elít. In Monitoring divadiel na Slovensku. ISSN 2454-0129. [online]. [cit. 8. 10. 2017]. Dostupné na internete: https://www.monitoringdivadiel.sk/recenzie/ recenzia/paralelne-zivoty-elit/.

ŠMATLÁKOVÁ, Lucia. Slovač, národ krkavčí? In Monitoring divadiel na Slovensku. ISSN 24540129. [online]. [cit. 7. 10. 2017]. Dostupné na internete: https://www.monitoringdivadiel.sk/ recenzie/recenzia/slovac-narod-krkavci/.

VEDRAL, Jan. Divadlo disensu v tekuté epoše dědiců Johanna Christiana Woyzecka. In Má mat' divadlo zmysel? Zborník referátov z VIII. medzinárodnej banskobystrickej teatrologickej konferencie $v$ cykle DNES A TU. (Ed. Andrej Matašík). Banská Bystrica : Akadémia umení v Banskej Bystrici, Fakulta dramatických umení, 2010, s. 57 - 65. ISBN 978-80-89078-79-0.

VEDRAL, Jan. Horizont události. Praha - Bratislava : Nakladatelství Pražská scéna - Ústav divadelnej a filmovej vedy SAV, 2015, 285 s. ISBN 978-80-86102-95-5.

Vojenské meno Rama - Slovenské Tour. [online]. [cit. 14 3. 2018]. Dostupné na internete: http:// www.poton.sk/aktuality/vojenske-meno-rama-slovenske-tour/.

Vojenské meno Rama : Divadlo Pôtoň. [Bulletin k inscenácii]. Bátovce : Divadlo Pôtoň, 2017, nestránkované.

ULIČIANSKA, Zuzana. Sága rodu Esterházyovcov. In Monitoring divadiel na Slovensku. ISSN 2454-0129 [online]. [cit. 7. 4. 2018]. Dostupné na internete: https://www.monitoringdivadiel. sk/recenzie/recenzia/saga-rodu-esterhazyovcov/. 
ZIMA, Peter V. Theorie des Subjekts: Subjektivität und Identität zwischen Moderne und Postmoderne. Tübingen : UTB / Francke, 2000, 468 s. ISBN 9783825221768.

Elena Knopová

Ústav divadelnej a filmovej vedy CVU SAV

Dúbravská cesta 9

84101 Bratislava

e-mail: elena.knopova@savba.sk 